\title{
The Fe-Zn Isotopic Characteristics and Fractionation Models: Implications for the Genesis of the Zhaxikang Sb-Pb-Zn-Ag Deposit in Southern Tibet
}

\author{
Da Wang, ${ }^{1,2}$ Youye Zheng $\mathbb{D}^{1,3}$ Ryan Mathur ${ }^{1}{ }^{2},{ }^{2}$ and Song $W u^{1}$ \\ ${ }^{1}$ State Key Laboratory of Geological Processes and Mineral Resources, School of Earth Sciences and Resources, \\ China University of Geosciences, Beijing 100083, China \\ ${ }^{2}$ Department of Geology, Juniata College, Huntingdon, PA 16652, USA \\ ${ }^{3}$ State Key Laboratory of Geological Processes and Mineral Resources and Faculty of Earth Resources, China University of Geosciences, \\ Wuhan 430074, China
}

Correspondence should be addressed to Youye Zheng; zhyouye@163.com and Ryan Mathur; MATHURR@juniata.edu

Received 30 August 2017; Revised 17 December 2017; Accepted 21 January 2018; Published 20 March 2018

Academic Editor: Bin Chen

Copyright (C) 2018 Da Wang et al. This is an open access article distributed under the Creative Commons Attribution License, which permits unrestricted use, distribution, and reproduction in any medium, provided the original work is properly cited.

The genesis of the Zhaxikang Sb-Pb-Zn-Ag deposit remains controversial. Three different geological environments have been proposed to model mineralization: a hot spring, a magmatic-hydrothermal fluid, and a sedimentary exhalative (SEDEX) overprinted by a hot spring. Here, we present the electron probe microanalysis (EPMA) and Fe-Zn isotopic data (microsampled) of four samples from the first pulse of mineralization that show annular textures to constrain ore genesis. The $\mathrm{Zn} / \mathrm{Cd}$ ratios from the EPMA data of sphalerite range from 296 to 399 and overlap the range of exhalative systems. The $\delta^{56} \mathrm{Fe}$ values of MnFe carbonate and $\delta^{66} \mathrm{Zn}$ values of sphalerite gradually decrease from early to late stages in three samples. A combination of the EPMA and isotopic data shows the Fe- $\mathrm{Zn}$ contents also have different correlations with $\delta^{66} \mathrm{Zn}$ values in sphalerite from these samples. Rayleigh distillation models this isotope and concentration data with the cause of fractionation related to vapour-liquid partitioning and mineral precipitation. In order to verify this Rayleigh distillation model, we combine our Fe-Zn isotopic data with those from previous studies to establish $12 \mathrm{Fe}-\mathrm{Zn}$ isotopic fractionation models. These fractionation models indicate the $\delta^{56} \mathrm{Fe}_{i}$ and $\delta^{66} \mathrm{Zn}_{i}$ values (initial Fe- $\mathrm{Zn}$ isotopic compositions) of the ore-forming system are in the range of $-0.5 \%$ o $-1 \%$ and $-0.28 \%$ o $0 \%$, respectively. To conclude, the EPMA data, Fe-Zn isotopic characteristics, and fractionation models support the SEDEX model for the first pulse of mineralization.

\section{Introduction}

To date, the Zhaxikang Sb-Pb-Zn-Ag deposit is the only super large deposit that has been identified within the North Himalayan Polymetallic Metallogenic Belt (NHMB). Although basic research including the geology, petrography, geochronology, and geochemistry studies has been conducted (e.g., $[1,2])$, the genesis of this deposit is still debated due to the complicated mineralogy and the presence of multiple stages of mineralization. The main viewpoints involve a hot spring $[3,4]$, two magmatichydrothermal fluids $[5,6]$, and a SEDEX overprinted by hot spring [7] genetic models. However, most of these genetic models are based on the $\mathrm{S}, \mathrm{C}, \mathrm{O}, \mathrm{H}$, and $\mathrm{Si}$ isotopic evidence, which cannot absolutely trace the metal source.

The traditional light stable $\mathrm{C}, \mathrm{H}, \mathrm{O}, \mathrm{S}$, and $\mathrm{N}$ isotopes have been widely used to constrain fluid evolution and metal sources in ore deposit studies (e.g., $[8,9])$. However, the evidences for metal source from these elements are always indirect and putative as they are not the metallogenic elements themselves [10]. For instance, these elements usually have different characteristics with the changing of tectonic settings, and sometimes they may even have different sources from the metallogenic elements [11]. However, the nontraditional transition metal stable isotopes (e.g., $\mathrm{Fe}, \mathrm{Zn}, \mathrm{Cu}, \mathrm{Cd}$, $\mathrm{Mg}, \mathrm{Cr}, \mathrm{Sn}$, and Mo) are more precise tracers for the metal sources and ore-forming processes in metallogenic systems 
$[10,12,13]$. The development of Multicollector-Inductively Coupled Plasma Mass Spectrometer (MC-ICP-MS) technology has greatly improved the precision of isotopic analyses $[14,15]$, which results in the wide application of the nontraditional transition metal stable isotopes in economic geology studies (e.g., $[16,17])$.

The $\mathrm{Fe}-\mathrm{Zn}$ isotopes are two of the most representative isotopes applied in ore deposit studies. For example, Mason et al. [18] and Wilkinson et al. [19] both identified that the $\delta^{66} \mathrm{Zn}$ values of minerals precipitating from the same hydrothermal fluid become heavier over time by studying the $\mathrm{Zn}$ isotopic fractionation of the Alexandrinka volcanic hosted massive sulfide (VHMS) type deposit in Russia and Midlands Irishtype deposit in Ireland, respectively. The gradual increasing $\delta^{66} \mathrm{Zn}$ values both from early to late stages and from south to north within the Red Dog ore district in Alaska record the temporal-spatial evolution of the ore-forming fluid and constrain the SEDEX genesis with a single Zn source [20]. In addition, $\mathrm{Fe}$ isotopic studies of skarn $\mathrm{Cu}-\mathrm{Au} \pm \mathrm{Fe}$ deposits in South China excluded the possibility that $\mathrm{Fe}$ originated from sedimentary strata $[21,22]$. These Fe isotopes matched the igneous source rocks and mineralization, and the $\delta^{56} \mathrm{Fe}$ values of sulfides gradually increase both from early to late stages and away from the ore-related igneous rocks. Wang et al. [21, 22] also revealed that the Fe isotopes fractionate during fluid exsolution and that the ore-forming fluid is enriched in light isotopes relative to ore-related igneous rocks. To the contrary, Wawryk and Foden [23] investigated the Fe-isotope fractionation in the Renison Sn-W deposit in Australia and discovered that $\mathrm{Fe}$ isotopic compositions of pyrite $\left(0.61 \%_{0} \sim 1.14 \%\right.$ ), chalcopyrite $(0.18 \%$ o $0.71 \%$ ), and magnetite $\left(0.50 \% 0_{0} \sim 0.70 \%\right.$ ) are isotopically heavier than Renison granite $(0.27 \%$ o $0.45 \%$ o $)$ and thus hypothesized that a magmatic-hydrothermal fluid exsolved from an isotopically heavy reduced magma could deposit isotopically heavy ore minerals whereas oxidized magmas crystallise magmatic magnetite could result in an isotopically lighter melt and fluid. These studies demonstrate the potential of $\mathrm{Fe}-\mathrm{Zn}$ isotopes to trace the metal source and provide insights into ore-forming evolution.

With regard to the Zhaxikang deposit, Duan et al. [5] have investigated the $\mathrm{Zn}$ isotope of sphalerite, galena, Fe$\mathrm{Mn}$ carbonates, and igneous rocks and speculated that the $\delta^{66} \mathrm{Zn}$ values of the hydrothermal fluid are $0.39 \pm 0.10 \%$. This value is consistent with those of basement rocks (average value of $0.36 \%$ $\pm 0.03 \%$ ) and Fe-Mn carbonates (average value of $0.27 \%$ o $\pm 0.15 \%$ o), which is identified as the evidence for the magmatic origin. Meanwhile, the contribution of regional sedimentary rocks is conjectured by the $\mathrm{Zn}-\mathrm{Pb}-\mathrm{S}$ isotopes: (1) the $\mathrm{Zn}$ isotopic variation range of sulfides $(-0.25 \% 0 \sim 0.03 \%$ o $)$ is larger than basement rocks $(0.05 \%$ o $0.21 \%$ o); (2) the radiogenic $\mathrm{Pb}$ isotopic compositions of sulfides (e.g., ${ }^{206} \mathrm{~Pb} /{ }^{204} \mathrm{~Pb}=18.727 \sim 19.896$ ) is higher than regional igneous rocks $\left({ }^{206} \mathrm{~Pb} /{ }^{204} \mathrm{~Pb}=18.4 \sim 19.2\right)$; (3) the $\delta^{34} \mathrm{~S}$ values of sulfides $(6 \%$ o $12 \%$ o) are lighter than regional sedimentary wall rocks $(10.94 \%$ o $11.49 \%$ o but higher than mantle value $(0 \pm 2 \%)$. However, the $\mathrm{Zn}$ isotopic fractionation during the fluid exsolution and leaching process
$[27,28]$ has been ignored in Duan et al. [5]. In addition, Wang et al. [26] also studied the Fe- $\mathrm{Zn}$ isotopes of the pyrite, sphalerite, and Mn-Fe carbonate in Zhaxikang deposit, which successfully constrained the two pulses of mineralization by the temporally increasing $\delta^{56} \mathrm{Fe}$ and decreasing $\delta^{66} \mathrm{Zn}$ values recorded in the deposit that coincided with an increase in alteration. The Fe- $\mathrm{Zn}$ isotopic research also demonstrated the magmatic-hydrothermal fluid origin of the second pulse of mineralization by the heavier $\delta^{56} \mathrm{Fe}$ values of stage 3 pyrite and excluded the possibility that slate is the metal source by the similar $\delta^{66} \mathrm{Zn}$ values of slate and sphalerite. Nevertheless, the attempt to trace the metal source of the first pulse of mineralization failed in Wang et al. [26]. In this study, we present the $\mathrm{Fe}-\mathrm{Zn}$ isotopic values and variations within four annular polished section samples from Zhaxikang deposit to provide more credible evidence for the primary and earlier stages of ore genesis.

\section{Geological Setting}

2.1. Regional Geology. The NHMB is in the eastern section of the North Himalayan Tectonic Belt $(\mathrm{NH})$, in the Himalayan terrane. From north to south, the Himalayan terrane is divided into four tectonic belts: the North Himalayan Tethys Sedimentary Fold Belt (the North Himalayan Tectonic Belt; $\mathrm{NH})$, the High Himalayan Crystalline Rock Belt $(\mathrm{HH})$, the Low Himalayan Fold Belt (LH), and the Sub-Himalayan Tectonic Belt (SH; Figure 1(a)) [29-31]. These belts are separated by four nearly EW-trending faults, including the South Tibet Detachment System (STDS), the Main Central Thrust (MCT), the Main Boundary Thrust (MBT), and the Main Frontal Thrust (MFT; Figure 1(a)) [24, 32]. The $\mathrm{NH}$, composed of a set of Palaeozoic marine sedimentary sequences that formed in a passive continental margin environment within northern India [33], is located between the Indus-Yarlung Zangbo Suture Zone (IYZS) and the HH (Figure 1(a)).

The sedimentary sequence in the NH records Late Precambrian to Devonian prerift, Carboniferous to Early Jurassic syn-rift and Middle Jurassic to Cretaceous passive continental margin sediments (Figure 1(b)) [66-68]. These sediments crop out in an EW and NWW trend and are predominated by the Precambrian Laguigangri Group and a series of Upper Triassic, Jurassic, Lower Cretaceous, and Quaternary sediments. The Laguigangri Group crops out in the core of the Yelaxiangbo dome and is composed of schist, gneiss, and migmatite units (Figure 1(b)). A set of Late TriassicEarly Cretaceous flysch formations deposit in neritic-bathyal environments and crop out across the NH. This set of formations are dominated by turbidite deposits and host the majority of the Au-Sb-Pb-Zn-Ag deposits in the $\mathrm{NH}$. The lithology of these Late Triassic-Early Cretaceous flysch formations is weak-metamorphic slate that is intercalated with metamorphosed fine-grained sandstone, argillaceous limestone, micrite, and siliceous rock that is intercalated with volcanic rocks [7]. Some quaternary sediments also occur in the central and southern area of the $\mathrm{NH}$, which are composed of gravel, sand gravel, sandy loam, clay, and ice boulder. 

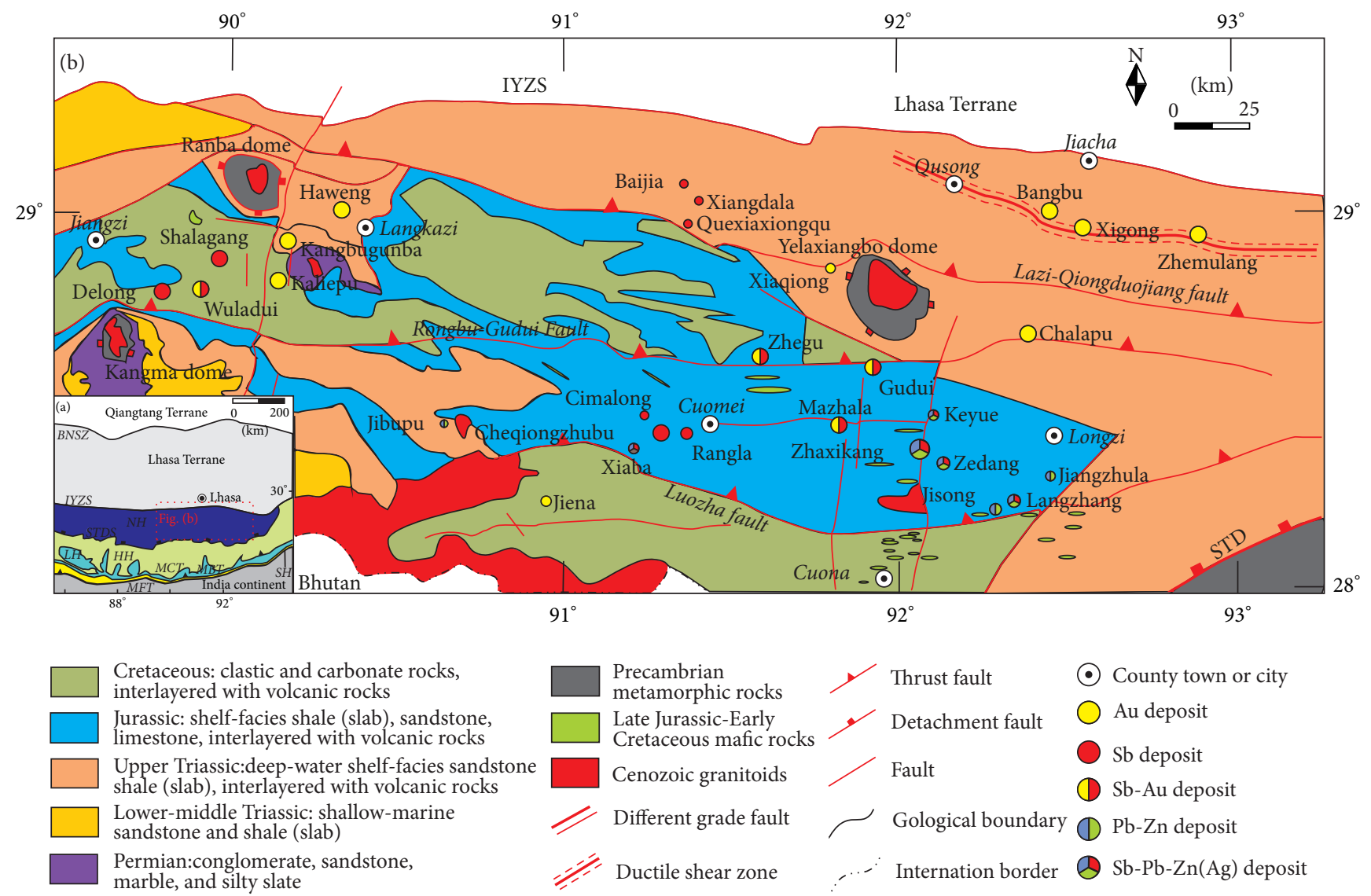

Figure 1: (a) Tectonic framework of the Himalayan Terrane (modified from Yin [24]). (b) Regional geological map of the North Himalayan Polymetallic Metallogenic Belt (modified from Zheng et al. [25]). BNSZ: the Bangong-Nujiang Suture Zone; IYZS: the Indus-Yarlung Zangbo Suture Zone; STDS: the South Tibet Detachment System; MCT: the Main Central Thrust Fault; MBT: the Main Boundary Thrust Fault; MFT: the Main Frontal Thrust; NH: the North Himalayan Tethys Sedimentary Fold Belt; HH: the High Himalayan Crystalline Rock Belt; LH: the Low Himalayan Fold Belt; SH: the Sub-Himalayan Tectonic Belt.

The EW-trending and NS-trending faults, both with the several episodes of motion, are present in the NH. The EWtrending faults, controlling the distribution of intermediateacid magmatic rocks and ore deposits in the $\mathrm{NH}$ [7], are older and cover a larger area than the NS-trending faults. The representative EW-trending faults include the LaziQiongduojiang, Rongbu-Gudui, and Luozha faults as well as the STDS and numerous metamorphic core complexes (Figure 1(b)). A series of rifts that formed from $25 \mathrm{Ma}$ to present are associated with these faults [29, 69-71], mainly including the Sangri-Cuona, Yadong-Gulu, Shenzha-Xietongmen, and Dangreyongcuo-Gucuo rift zones from east to west [72]. In addition, the NS-trending faults that are considered as the result of east-west extension of the Qinghai-Tibet Plateau $[73,74]$ also formed during this period especially from 18 to $4 \mathrm{Ma}[75,76]$. These NS-trending faults are also the important ore-controlling structures in the $\mathrm{NH}$ [1].

Magmatism in the NH primarily includes the Mesozoic and Cenozoic magmatism. The Mesozoic magmatism generated multiple suites of mafic-intermediate igneous rocks between the Late Triassic and the Early Cretaceous, including basaltic volcanic interlayers, dyke swarms, and subvolcanic dykes. According to the previous geochronological data, the SHRIMP U-Pb ages of the basic dyke swarms from different area in the $\mathrm{NH}$ are $134.9 \pm 1.8 \mathrm{Ma}, 135.5 \pm 2.1 \mathrm{Ma}$ [77], and $138.0 \pm 3.5 \mathrm{Ma}$ [78], respectively. The SHRIMP $\mathrm{U}-\mathrm{Pb}$ age of the gabbro is $155.8 \mathrm{Ma}$ [79]. Tong et al. [78], Pan et al. [80], and Zhong et al. [81] regarded these basic dyke swarms as the result of late-stage massive expansion of Neo-Tethys Ocean under the structural environment of the Himalaya passive continental margin intensive stretching and breaking-off, lithosphere extension-thinning, and asthenosphere upwelling. On the contrary, Zhu et al. [82] and Qiu et al. [83] suggested that these basic dyke swarms are the result of interaction between mantle plume and lithospheric mantle material and form in the continental-rift environment. The Cenozoic magmatism is characterized by the formation of monzogranite, leucogranite, diorite, porphyritic diorite, and aplite units $[84,85]$. These Cenozoic intermediate-acidic intrusive masses are distributed along the $\mathrm{EW}$-trending faults and in the core of Ranba, Kangma, and Yelaxiangbo dome in the form of batholith, laccolith, and dykes (Figure 1(b)). This phenomenon is considered to be the result of crustal thickening [86] related to the collision of the India Plate and the Eurasia Plate during the postcollision stage ( 25 to $0 \mathrm{Ma}$ ) $[87,88]$. 
The NHMB contains many $\mathrm{Sb}, \mathrm{Au}, \mathrm{Sb}-\mathrm{Au}, \mathrm{Pb}-\mathrm{Zn}$, and $\mathrm{Sb}-\mathrm{Pb}-\mathrm{Zn}$-Ag deposits, and the Zhaxikang Sb-Pb-Zn-Ag, the Mazhala Au-Sb, the Chalapu Au, the Bangbu Au, the Shalagang $\mathrm{Sb}$, the Cheqiongzhuobu $\mathrm{Sb}$ deposits are representative (Figure 1(b)) [7, 25]. The geneses and metallogenic age of these deposits are controversial due to the limited research, the genetic models mainly include the SEDEX overprinted by hot spring, carlin and carlin-like, hot spring, subvolcanic magmatic-hydrothermal fluid, and orogenic types [25].

2.2. Ore Deposit Geology. The Zhaxikang Sb-Pb-Zn-Ag deposit is located $\sim 48 \mathrm{~km}$ west from Longzi County Town within the southeastern Yangzuoyong-Nariyong composite syncline in the NH (Figure 1(b)). This deposit has a reserve of $1.268 \mathrm{Mt} \mathrm{Pb}-\mathrm{Zn}$ with a $3.66 \%$ average $\mathrm{Zn}$ grade and a $2.45 \%$ average $\mathrm{Pb}$ grade, $0.138 \mathrm{Mt} \mathrm{Sb}$ with an average grade of $1.08 \%, 1800 \mathrm{t}$ Ag with an average of $99.55 \mathrm{~g} / \mathrm{t}, 3.9 \mathrm{t}$ associated $\mathrm{Au}, 361 \mathrm{t}$ associated $\mathrm{Ga}$, and $20 \mathrm{Mt} \mathrm{Mn-Fe} \mathrm{carbonate} \mathrm{ores}$ with an average grade of $42 \%$ for $\mathrm{Fe}+\mathrm{Mn}$ [89], which makes it the largest deposit within the NHMB. The majority of mineralization in the orefield is hosted by the Lower Jurassic Ridang formation that consists of epimetamorphic marine clastic rocks. This formation, dipping shallowly to the north and striking eastwest, is divided into five lithologic sections (Figure 2(a)). A few Upper Jurassic Weimei formations composed of fine-grained metamorphic quartzose sandstone, silty slate, and calcarenite as well as Quaternary sediments distributed along valleys also crop out in the orefield (Figure 2(a)) [7].

The Zhaxikang deposit developed extensive geological structures. A near northsouth striking fault system is prevalent in the orefield, which coexists with a group of northeaststriking faults and some folds. Engineering and geological mapping projects have identified 16 faults, the majority of which are steeply dipping normal faults associated with tensional stress and wrench faults associated with torsional stress. Faults F2, F4, F5, F6, F7, F13, F14, and F16 are the main ore-bearing faults, faults $\mathrm{F} 1$ and F10 are partly mineralized, fault F3 was associated with late-stage mineralization, faults F8 and F9 are wrench faults without any mineralization, and fault F12 is a nonmineralized regional fault (Figure 2(a)). The orebodies I-VI are hosted by nearly NS-striking faults and orebodies VII-IX are hosted by nearly NE-striking faults (Figure 2). Our samples in this study are all from the orebody $\mathrm{V}$, which is the largest and richest one among these orebodies within the orefield and hosts more than $80 \%$ of the reserves. This orebody is $>1400 \mathrm{~m}$ long, 1 to $30 \mathrm{~m}$ wide, and controlled by fault F7 (Figure 2).

The magmatism in the orefield is associated with diabase, porphyritic rhyolite, basalt, and leucogranite units as well as some granite porphyry dykes that intruded into the porphyritic rhyolite (Figure 2(a)). The diabase is identified by drillholes and footrill in the central part of the orefield as dykes that emplaced into the Jurassic Ridang Formation and has been dated by zircon U-Pb methods to $\sim 133 \mathrm{Ma}$ [7]. The rhyolite porphyry with the zircon SHRIMP U-Pb age of $\sim 135$ Ma crops out in the western part of the orefield [90] and the leucogranites crop out in the southern part of the orefield over an area of $<1 \mathrm{~km}^{2}$. Additionally, the basalt usually occurs near the orebody in the form of consequent layer or shear layer distributed in slate and the contact region of slate and diabase.

Various types of alteration associated with mineralization have occurred in the orefield, including (1) the silicification that is associated with $\mathrm{Sb}$ mineralization and generally located in fault zones in the form of quartz veins, radiating quartz, and quartz druse; (2) the carbonatization that is associated with $\mathrm{Pb}-\mathrm{Zn}$ mineralization in the form of $\mathrm{Mn}$ Fe carbonate veins and also formed the postmineralization calcite; (3) the chlorite alteration that is generally confined to massive and stellated aggregates of chlorite within diabase; (4) the weak sericite alteration that is associated with chlorite alteration and barren quartz; and (5) the clay alteration that developed along the edges of fracture-related crushed zones. Furthermore, the ore-forming elements display a vertical sequence that is zoned from a lowermost $\mathrm{Zn}(\mathrm{Pb}+\mathrm{Ag})$ zone through a central $\mathrm{Zn}+\mathrm{Pb}+\mathrm{Ag}-(\mathrm{Sb})$ zone to an uppermost $\mathrm{Pb}+\mathrm{Zn}+\mathrm{Sb}+\mathrm{Ag}$ zone, although no horizontal zoning is present [89].

2.3. Ore Paragenetic Sequence. The paragenetic sequence in the Zhaxikang deposit is divided into six stages of ore formation based on the detailed hand specimen and microscopic observations. These six stages are assigned to two clear pulses: the first pulse consists of stages 1 to 2 and is characterized by the assemblages of Mn-Fe carbonates and sulfides, and the second pulse includes stages 3 to 6 and is primarily dominated by quartz, calcite, sulfosalt minerals, and sulfides (Figure 3).

Stage 1 , dominated by a $\mathrm{Mn}-\mathrm{Fe}$ carbonate + sphalerite + pyrite + arsenopyrite assemblage, is the initial stage of ore formation in the Zhaxikang deposit. Majority of the fine-grained sphalerite, pyrite, and arsenopyrite are hosted by fine-grained $\mathrm{Mn}-\mathrm{Fe}$ carbonate in the form of laminae (Figures 4(a)-4(c)), and a few sulfides occur within the MnFe carbonates as stellated aggregates (Figure 4(d)). The finegrained layered and colloform with synsedimentary features (Figure 4(b)). The laminae and Mn-Fe carbonates in some samples have been cut by later stage 4 quartz-boulangerite veins (Figure $4(\mathrm{c})$ ) or have been affected by the stage 2 coarsegrained sphalerite (Figure 4(a)).

Stage 2 hosts majority of the $\mathrm{Pb}-\mathrm{Zn}$ mineralization in the Zhaxikang deposit and comprises an assemblage of MnFe carbonate + galena + sphalerite + pyrite \pm arsenopyrite. The more abundant and coarser-grained sulfides are hosted by coarse-grained $\mathrm{Mn}-\mathrm{Fe}$ carbonate and slate to form the banded (Figure 4(k)), net-veined (Figure 4(i)), massive (Figure 4(h)), concentric annular (Figures 4(g) and 5), and Dal Matianite (Figure 4(l)) ores. The Mn-Fe carbonate during this stage recrystallized to different degree (Figures 4(f), 4(g) and $4(\mathrm{i})-4(\mathrm{k}))$, some even formed the druse containing the idiomorphic columnar quartz, needle-like boulangerite, or valentinite (Figure 4(j)). We can also observe that the later sphalerite replaces the earlier pyrite containing automorphic stage 1 arsenopyrite to form a skeletal texture during this stage (Figure 4(w)). Zheng et al. [7] considered that the ore textures in stages 1 and 2 are similar to those of the Red Dog SEDEXtype ore district in Alaska. 


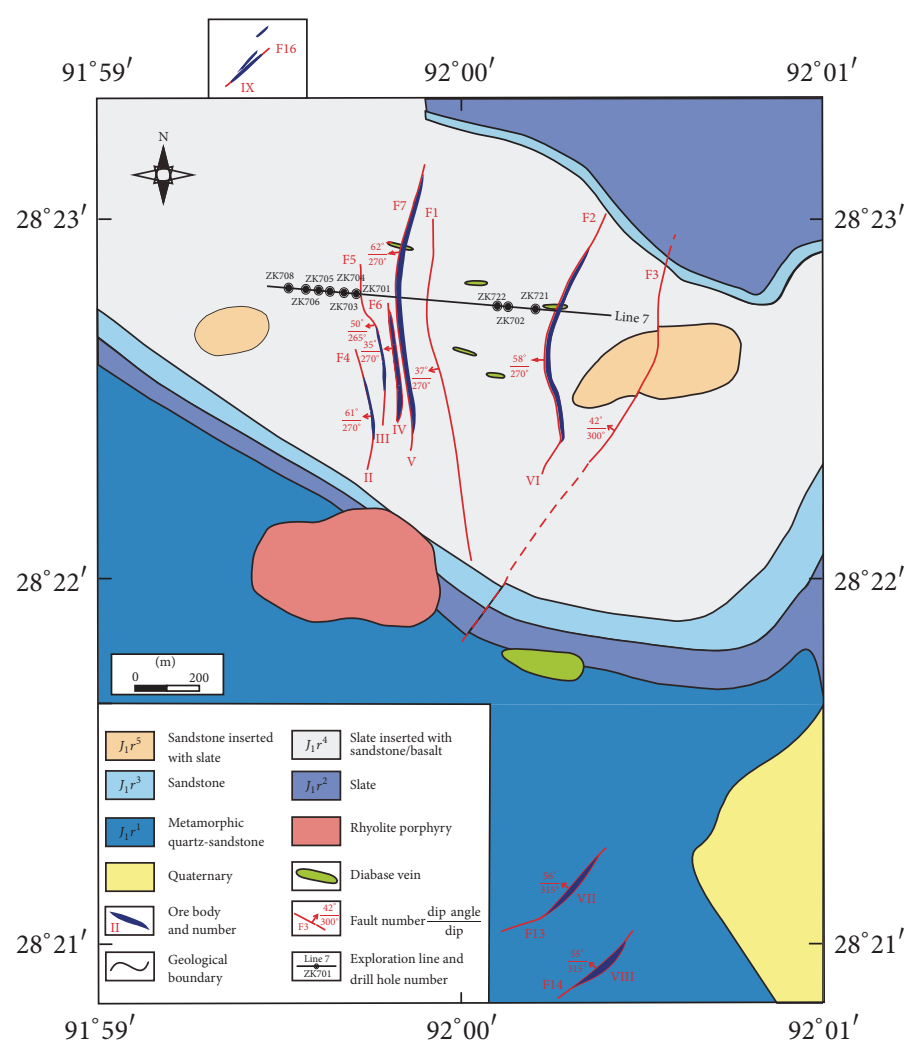

(a)

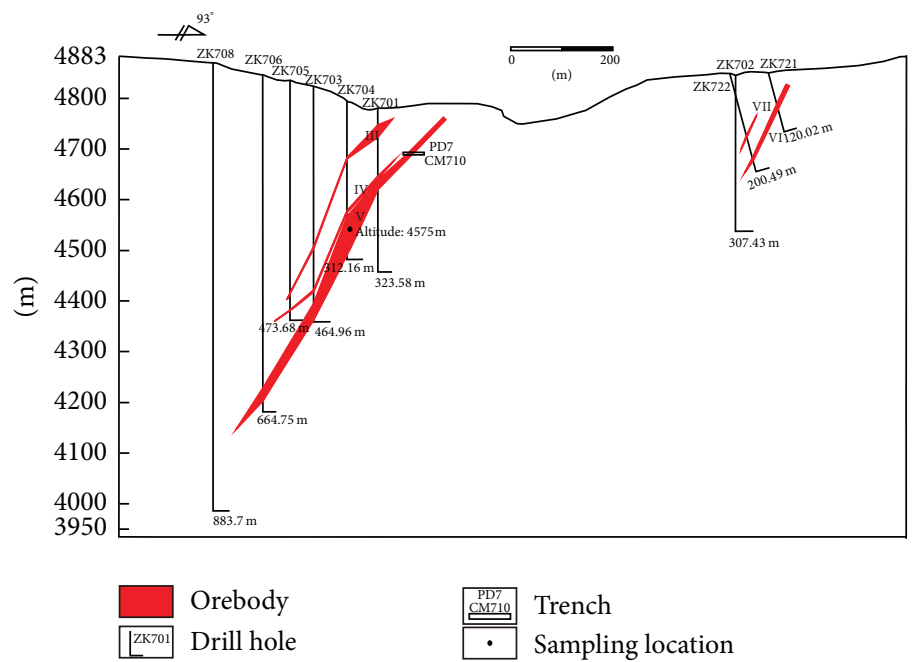

(b)

Figure 2: (a) Geological map of the Zhaxikang Sb-Pb-Zn-Ag polymetallic deposit (modified from Zheng et al. [7]). (b) Cross-section along Exploration Line 7. $J_{1} r^{1}$ to $J_{1} r^{5}$ : the first to fifth lithologic section of the Lower Jurassic Ridang formation.

Stage 3 , characterized by the formation of a quartz \pm calcite + pyrite + sphalerite + galena \pm chalcopyrite \pm arsenopyrite assemblage without $\mathrm{Mn}-\mathrm{Fe}$ carbonate, is the earliest stage of the second pulse of mineralization. The massive, veined, net-veined, and brecciated sphalerite, galena, and pyrite occur in the quartz and calcite (Figures 4(l)-4(p), $4(\mathrm{x}))$, and most of the sulfides form by the modification of sulfides from earlier stages. Some chalcopyrite grains are distributed in sphalerite, galena, and pyrite as stellated aggregates (Figures 4(y) and 4(z)). Some of these sulfides have been cross-cut by the later quartz-boulangerite or quartzcalcite veins (Figure 4(o)).

Stage 4 is marked by a mineral assemblage composed of quartz + antimony-lead-silver sulfosalt minerals (Figure 4(r)) that prevailingly include boulangerite and jamesonite, as well as minor bournonite, tetrahedrite, and andorite. This stage hosts the majority of the Sb and Ag mineralization and yields the ores with relatively high average Ag grades. The minerals 


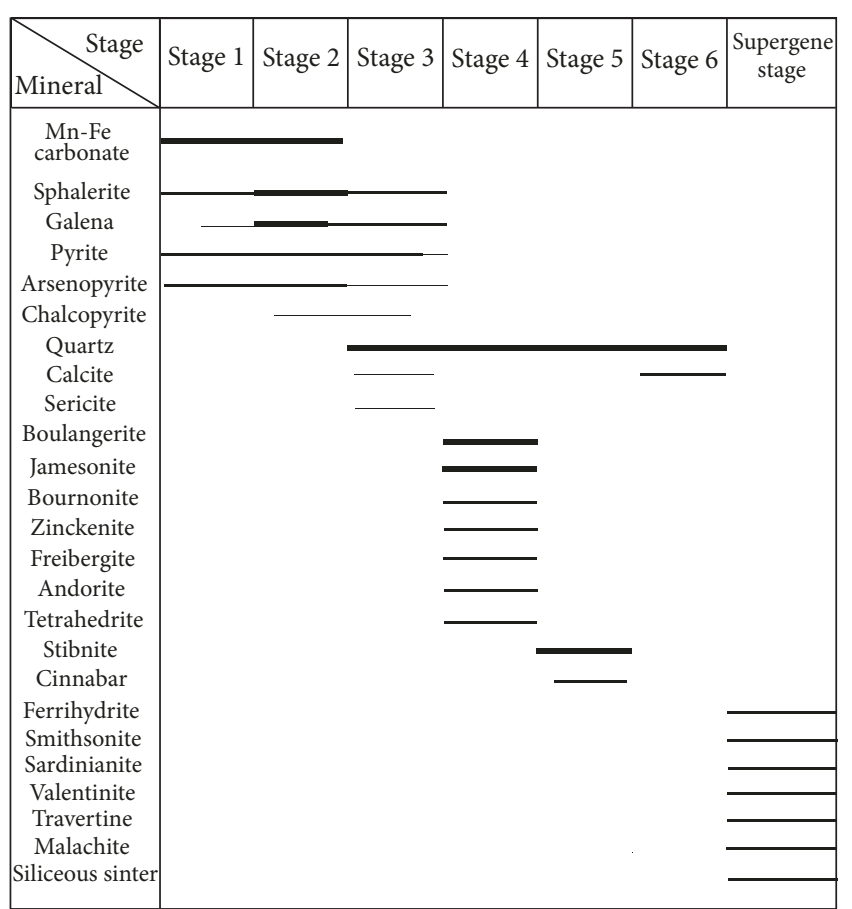

Notes:
$\begin{aligned} & \text { Abundant } \\ & \text { Intermediate } \\ & \text { Minor }\end{aligned}$

Figure 3: Mineral paragenesis within the Zhaxikang Sb-Pb-Zn-Ag deposit (modified from Wang et al. [26]).

formed in earlier stages are replaced and cross-cut by the quartz-boulangerite veins and boulangerite of this stage (Figures 4(c) and 4(aa)). Some samples also contain quartz druse filled with needle-like boulangerite (Figure 4(q)).

Stage 5 is distinguished by the formation of a quartz + stibnite + cinnabar assemblage and hosts part of the $\mathrm{Sb}$ mineralization within the deposit. Elongate-radial stibnite and massive stibnite-cinnabar are hosted by quartz (Figures $4(\mathrm{~s})$ and $4(\mathrm{t}))$. Some stibnite cross-cut the stage 4 boulangerite (Figure 4(aa)).

Stage 6, representing the youngest stage of mineralization in the Zhaxikang deposit, is identified by a quartz \pm calcite assemblage without sulfides. The quartz-calcite veins of this stage cross-cut the earlier formed minerals (Figures 4(o) and $4(\mathrm{ab}))$. Zheng et al. [7] regarded the ore textures in the second pulse of mineralization as typical hot spring type metallogenic features.

Supergene stage in the Zhaxikang deposit consists of ferrihydrite, smithsonite, sardinianite, valentinite, travertine, malachite, and siliceous sinter (Figures $4(\mathrm{u})$ and $4(\mathrm{v})$ ).

\section{Sampling and Analytical Methods}

3.1. Sampling. The sampling points for EPMA and Fe-Zn isotopic analyses (the powders are sampled by microdrill) are all in the annular polished section samples 9-3, 9-8, ZXK-1, and ZXK-2. The specific numbers, locations, and photomicrographs of these sampling points are given in Figures 5 and 6, respectively. These four samples are all from the first pulse of mineralization, only the sample ZXK-2 has been cut by a stage 3 quartz vein (Figure 5(d)).

3.2. EPMA. Chemical compositions of sulfide, Mn-Fe carbonate, and quartz were determined on a JEOL (Japan Electron Optics Laboratory) JXA-8100 electron microprobe (EMP) at the Second Institute of Oceanography, State Oceanic Administration of China. The accelerating voltage is $15 \mathrm{kV}$ for Mn-Fe carbonate and quartz and $20 \mathrm{kV}$ for sulfide, the beam current is $10 \mathrm{nA}$, the beam diameter is $1 \mu \mathrm{m}$, the secondary electronic resolution is $6 \mathrm{~nm}$ with the operating distance of $11 \mathrm{~mm}$, and the repeat accuracy of the sample stage is within $1 \mathrm{~nm}$. The standards are natural minerals and synthetic oxides as those of Sun et al. [2]. The correction program supplied by the manufacturer is used for matrix corrections $[91,92]$.

3.3. Fe-Zn Isotopic Analyses. Approximately 10-50 milligrams of sample powders was placed in $15 \mathrm{ml}$ Teflon jars and the solids were dissolved in $4 \mathrm{ml}$ of heated ultrapure aqua regia. The solutions were dried and then Fe and $\mathrm{Zn}$ were purified using the BioRad MP-1 anion exchange resin using the protocol from Maréchal et al. [14]. Yields from the columns were tested volumetrically on the ICP-OES at Pennsylvania State University and were all greater than 95\%. Isotope values are reported in the traditional per mil values (\%o).

The Fe isotopes were measured on the Neptune MC-ICPMS at Pennsylvania State University. The instrument setup, sample introduction, and running conditions are discussed in greater detail in Yesavage et al. [93]. Samples were diluted to a $3 \mathrm{ppm}$ Fe solution which produced approximately a $10 \mathrm{~V}$ signal on the shoulder to the argon interference peak $\left({ }^{56} \mathrm{Fe}\right.$ and ${ }^{40} \mathrm{Ar}^{16} \mathrm{O}$ ). Sample intensities matched the intensity of the bracketing standard within $10 \%$. Mass bias was corrected for by standard-sample-standard bracketing. In-house and international standards were measured throughout the sessions and yielded overlapping values of SRM-3126a $\delta^{56} \mathrm{Fe}$ $=0.33 \pm 0.08 \%$ o, $n=8$ (accepted values $\delta^{56} \mathrm{Fe}=0.34 \pm$ $0.1 \%$ o $2 \sigma$ ) [93], and HPS-WU $\delta^{56} \mathrm{Fe}=0.62 \pm 0.11 \%$ o, $n=8$ (accepted values $\delta^{56} \mathrm{Fe}=0.60 \pm 0.07 \%$ o $2 \sigma$ ) [34]. The samples are reported relative to the international standard IRMM$014\left(\delta^{56} \mathrm{Fe}(\%)=\left[\left({ }^{56} \mathrm{Fe} /{ }^{54} \mathrm{Fe}\right)_{\text {sample }} /\left({ }^{56} \mathrm{Fe} /{ }^{54} \mathrm{Fe}\right)_{\text {IRMM-014 }}-\right.\right.$ $1] \times 1000)$. Reported values are an average of two different measurements and the errors fall within the range $0.1 \%$ o $2 \sigma$ of the standards.

The $\mathrm{Zn}$ isotopes were measured on Neptune MC-ICP-MS at Rutgers University. Correction of mass bias for $\mathrm{Zn}$ using $\mathrm{Cu}$ (NIST 976) was employed for these samples as suggested in [94-97] and the corrected values were then bracketed by the standards. The samples are reported relative to the newly developed $\mathrm{Zn}$ isotope standard (AA-ETH; $\delta^{66} \mathrm{Zn}(\%$ ) $\left.=\left[\left({ }^{66} \mathrm{Zn} /{ }^{64} \mathrm{Zn}\right)_{\text {sample }} /\left({ }^{66} \mathrm{Zn} /{ }^{64} \mathrm{Zn}\right)_{\mathrm{AA}-\mathrm{ETH}}-1\right] \times 1000\right)$ and all the quoted data from previous literatures in this paper are converted relative to the AA-ETH standard $\left(\delta^{66} \mathrm{Zn}_{\mathrm{AA}-\mathrm{ETH}}=\right.$ $\delta^{66} \mathrm{Zn}_{\text {JMC 3-0749 L }}-0.28 \%$ ) [98]. We also compared the new 


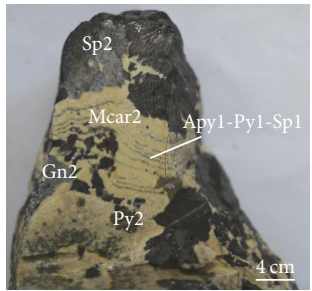

(a)

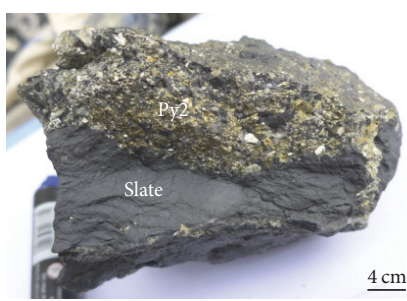

(e)

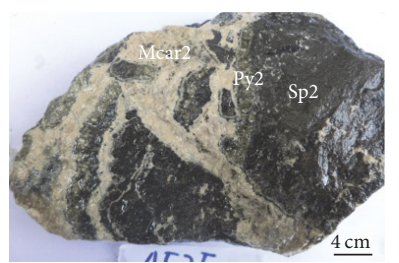

(i)

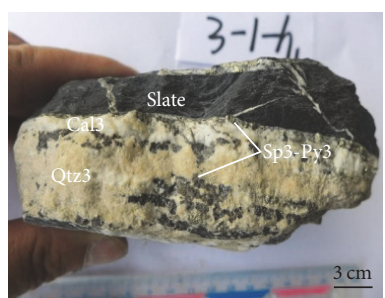

(m)

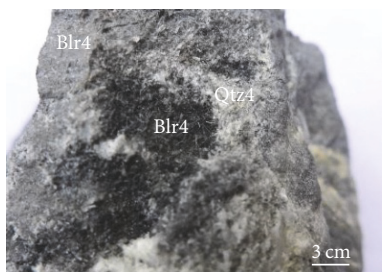

(q)

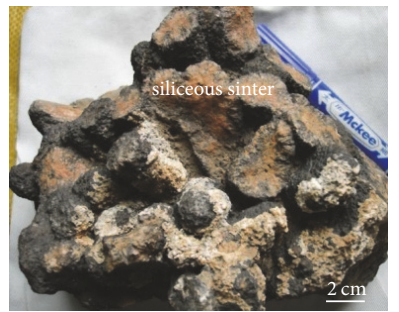

(u)

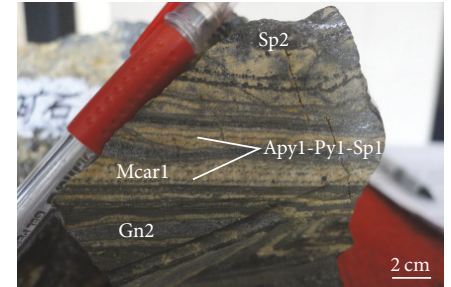

(b)

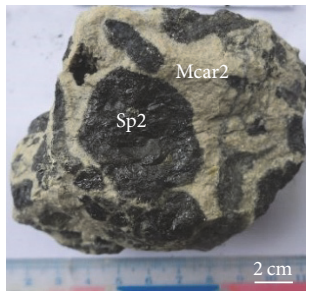

(f)

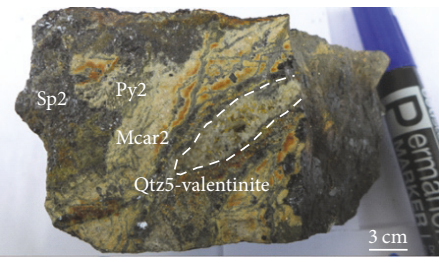

(j)

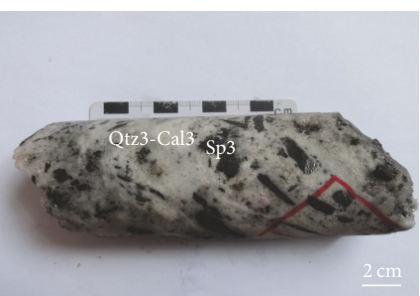

(n)

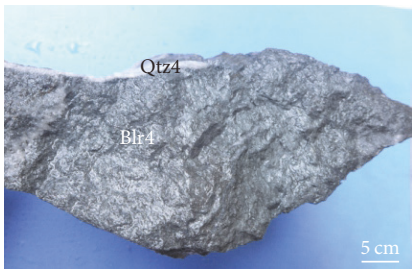

(r)

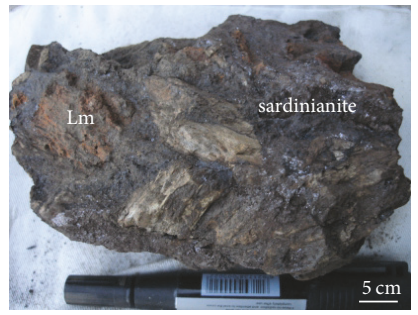

(v)

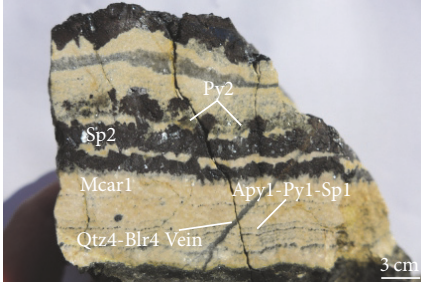

(c)

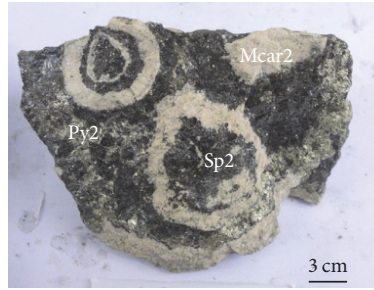

(g)

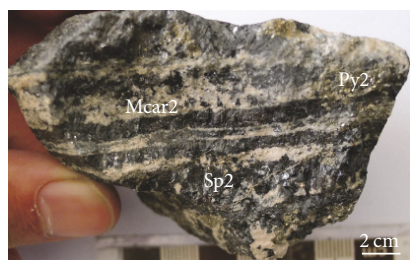

(k)

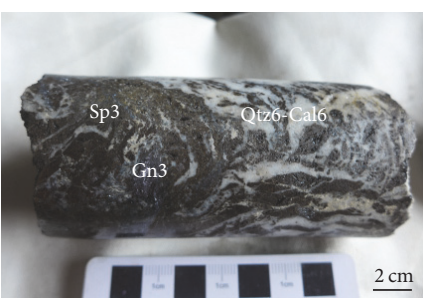

(o)

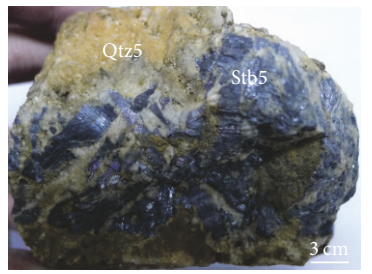

(s)

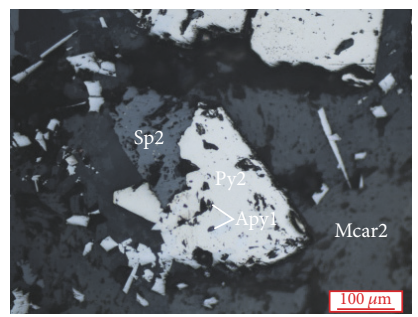

(w)

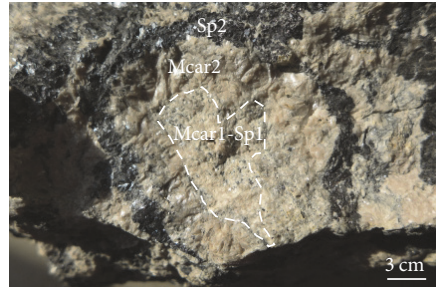

(d)

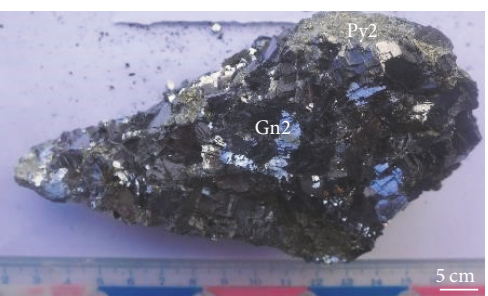

(h)

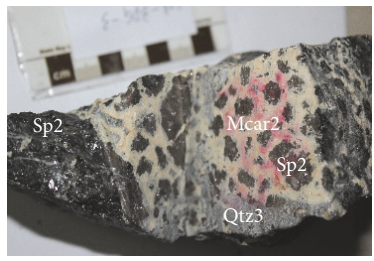

(1)

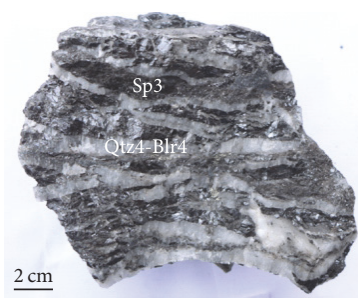

(p)

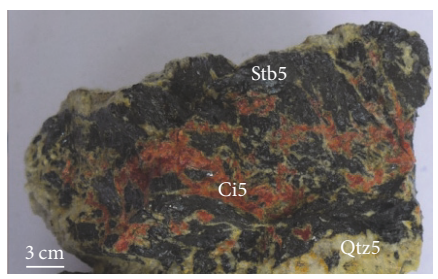

$(\mathrm{t})$

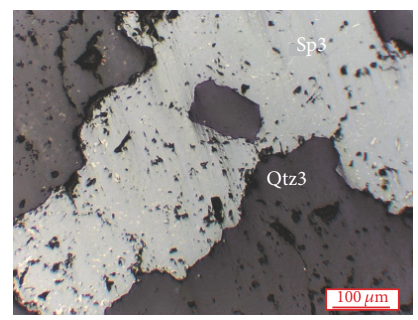

(x)

FIgURE 4: Continued. 


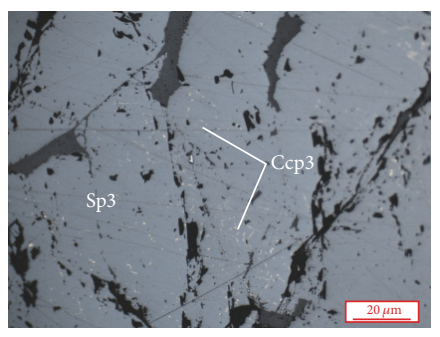

(y)

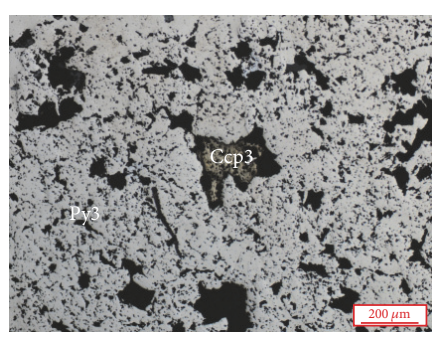

(z)

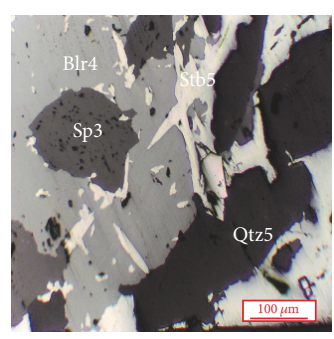

(aa)

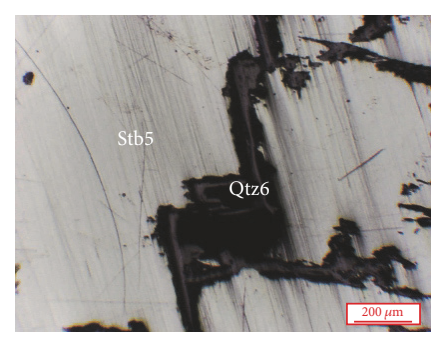

$(\mathrm{ab})$

FIgURE 4: Hand specimen photographs and photomicrographs of representative samples from the Zhaxikang deposit. (a) Stage 1 lamellar sphalerite-pyrite-arsenopyrite and stage 2 massive sphalerite-pyrite hosted within fine-grained Mn-Fe carbonate. (b) Stage 1 lamellar and stage 2 banded $\mathrm{Mn}$-Fe carbonate-sphalerite-galena ore with visible synsedimentary features including rhythmic sedimentation in the upper part and angular folding in the lower part of the sample. (c) Stage 1 lamellar sphalerite-pyrite-arsenopyrite and stage 2 massive and banded sphalerite-pyrite hosted by fine-grained $\mathrm{Mn}$-Fe carbonate. The mineral assemblage is in turn cross-cut by stage 4 quartz-boulangerite veins. (d) Coarse-grained stage $2 \mathrm{Mn}$-Fe carbonate-sphalerite formed by the recrystallization of fine-grained stage $1 \mathrm{Mn}$-Fe carbonate-sphalerite. (e) Stage 2 massive coarse-grained pyrite hosted by slate. (f) Massive and brecciated stage 2 sphalerite hosted in stage 2 Mn-Fe carbonate. (g) Stage 2 massive, globular, and concentric annular sphalerite-pyrite hosted by coarse-grained Mn-Fe carbonate. (h) Stage 2 massive galena and pyrite. (i) Stage 2 massive and veined sphalerite-pyrite hosted by coarse-grained Mn-Fe carbonate. (j) Stage 1 lamellar sphalerite-pyrite-arsenopyrite and stage 2 massive sphalerite hosted by fine-grained Mn-Fe carbonate. The sample also contains a Mn-Fe carbonate druse dominated by idiomorphic columnar quartz and valentinite. (k) Stage 2 coarse-grained sphalerite-pyrite hosted by stage 2 Mn-Fe carbonate with banded textures. (l) Stage 2 sphalerite and Mn-Fe carbonate ore with typical Dal Matianite texture. (m) Disseminated stage 3 sphalerite and pyrite hosted in stage 3 quartz and calcite, and stage 3 quartz and calcite cut the slate. (n) Stage 3 brecciated sphalerite within stage 3 quartz-calcite. (o) Stage 3 sphalerite-galena veins cross-cut by stage 6 quartz-calcite veins. (p) Stage 3 sphalerite cross-cut by stage 4 quartz-boulangerite veins. (q) Stage 4 massive and needle-like boulangerite hosted by stage 4 quartz. (r) Stage 4 boulangerite-quartz. (s) Stage 5 elongate stibnite hosted by stage 5 quartz. ( $\mathrm{t}$ ) Stage 5 stibnite-cinnabar hosted by stage 5 quartz. (u) Siliceous sinter formed during the Supergene stage. (v) Ferrihydrite and sardinianite formed during the Supergene stage. (w) Stage 2 pyrite containing automorphic stage 1 arsenopyrite is replaced by later stage 2 sphalerite to form a skeletal texture. (x) Stage 3 sphalerite occurs in stage 3 quartz. (y) The emulsion-like and disseminated stage 3 chalcopyrite grains are dotted in the stage 3 sphalerite. (z) The stage 3 chalcopyrite grains are dotted among the grains of stage 3 pyrite. (aa) Stage 3 sphalerite replaced by stage 4 boulangerite that is in turn cross-cut by stage 5 stibnite. (ab) Stage 5 stibnite cross-cut by stage 6 quartz. Mcarl = stage 1 fine-grained Mn-Fe carbonate; Apyl = stage 1 lamellar arsenopyrite; Pyl = stage 1 lamellar pyrite; Sp1 = stage 1 lamellar sphalerite; Mcar2 = stage 2 coarse-grained Mn-Fe carbonate; Apy2 = stage 2 arsenopyrite; Py2 = stage 2 pyrite; Sp2 = stage 2 sphalerite; Gn2 = stage 2 coarse-grained galena; Py3 = stage 3 pyrite; Sp3 = stage 3 sphalerite; Gn3 = stage 3 galena; Ccp3 = stage 3 chalcopyrite; Qtz3 = stage 3 quartz; Cal3 = stage 3 calcite; Blr4 = stage 4 boulangerite; Qtz $4=$ stage 4 quartz; Stb5 = stage 5 stibnite; Ci5 = stage 5 cinnabar; Qtz5 = stage 5 quartz; Cal6 = stage 6 calcite; Qtz6 = stage 6 quartz; Lm = Supergene stage ferrihydrite.

standard relative to IRMM 3702 and obtained a $\delta^{66} \mathrm{Zn}=$ $0.03 \%$, which is within the error reported in Archer et al. [98]. Solutions were kept at $100 \mathrm{ppb} \mathrm{Cu}$ and $150 \mathrm{ppb} \mathrm{Zn}$ which generated ${ }^{63} \mathrm{Cu}=7 \mathrm{~V}$ and ${ }^{66} \mathrm{Zn}=4 \mathrm{~V}$. One block of 30 ratios is reported and the average error for the standard compared to itself throughout the session is $0.05 \% 2 \sigma$.

\section{Results}

4.1. EPMA. All the EPMA data are given in Tables 1 and 2. The Mn-Fe carbonate contains 23.562 31.806 wt\% Fe and 27.514 $32.232 \mathrm{wt} \% \mathrm{Mn}$, with a negative correlation between Fe and Mn contents (Figure 7(a)), which indicates that the Mn-Fe carbonates form by the isomorphic substitution of $\mathrm{Fe}^{2+}$ and $\mathrm{Mn}^{2+}$ ions and have a molecular formula of $\left(\mathrm{Mn}_{0.5} \mathrm{Fe}_{0.5}\right) \mathrm{CO}_{3}$. The Fe contents are around $36 \mathrm{wt} \%$ for the arsenopyrite samples and $46 \mathrm{wt} \%$ for the pyrite samples. The sphalerite samples have 56.941 60.552 wt\% $\mathrm{Zn}$ and 5.375 9.424 wt\% Fe with a negative correlation between these two elements (Figure 7(b)).

4.2. $\mathrm{Fe}-\mathrm{Zn}$ Isotopes. All the Fe- $\mathrm{Zn}$ isotopic data are given in Table 3. The annular polished section samples have $\delta^{56} \mathrm{Fe}_{\text {IRMM-014 }}$ of $-1.95 \% 0 \sim 0.43 \%$, with an average of
$-0.50 \%$ o $1.09 \%$ o (2SD, $n=19)$, and $\delta^{66} \mathrm{Zn}_{\mathrm{AA}-\mathrm{ETH}}$ of $-0.38 \%$ o $0.07 \%$ with an average of $-0.25 \%$ o $\pm 0.19 \%$ ( 2 SD, $n=12)$. The $\mathrm{Mn}-\mathrm{Fe}$ carbonate and pyrite show the $\delta^{56} \mathrm{Fe}$ values range from $-1.95 \%$ to $-0.59 \%$ (average value of $-0.97 \%$ o $\pm 0.86 \%$; $2 \mathrm{SD}, n=8$ ) and from $-0.26 \%$ o to $0.23 \%$ o (average value of $-0.07 \%$ o $\pm 0.35 \%$; $2 \mathrm{SD}, n=9$ ), respectively. The two arsenopyrite samples exhibit the $\delta^{56} \mathrm{Fe}$ values of $-1.01 \%$ (ZXK-1-3; Figure 5(c)) and -0.18\%o (ZXK-2-2; Figure 5(d)).

In sample 9-3, the 9-3-1, 9-3-2 (Figure 6(a)), and 9-3-3 sphalerite have the $\delta^{66} \mathrm{Zn}$ values of $-0.12 \%$, $-0.23 \%$, and $-0.31 \%$ with a gradually decreasing trend, the 9-3-4 and 9-3$5 \mathrm{Mn}-\mathrm{Fe}$ carbonate show the same trend with the $\delta^{56} \mathrm{Fe}$ values of $-0.59 \%$ and $-1.95 \%$, and the $\delta^{56} \mathrm{Fe}$ value of 9-3-7 pyrite is $-0.26 \%$ (Figure $5(\mathrm{~b})$ ). Similarly, in sample 9-8, from 98-2 (-0.09\%o; Figure 6(c)) through 9-8-5 (-0.23\%o) to 9-8$3(-0.35 \%$; Figure $6(\mathrm{~d}))$, the $\delta^{66} \mathrm{Zn}$ values of sphalerite also present a gradually decreasing trend; meanwhile the $\delta^{56} \mathrm{Fe}$ values also decrease from $-1.06 \%$ o (9-8-8; Figure $6(\mathrm{~b}))$ to $-1.38 \%$ (9-8-9) for Mn-Fe carbonate and from $0.23 \%$ (9-84) to $0.09 \%$ o $(9-8-7)$ for pyrite, although the $9-8-1$ sphalerite and 9-8-6 pyrite have the $\delta^{66} \mathrm{Zn}$ value of $-0.17 \%$ and $\delta^{56} \mathrm{Fe}$ values of $-0.26 \%$ (Figure $5(\mathrm{a})$ ). In sample ZXK-1, the $\delta^{66} \mathrm{Zn}$ 


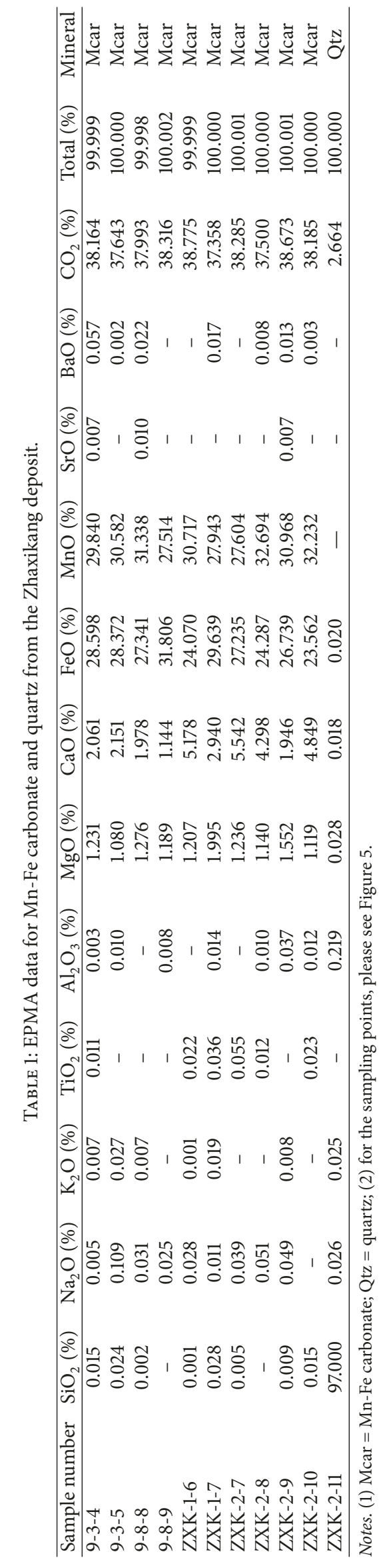




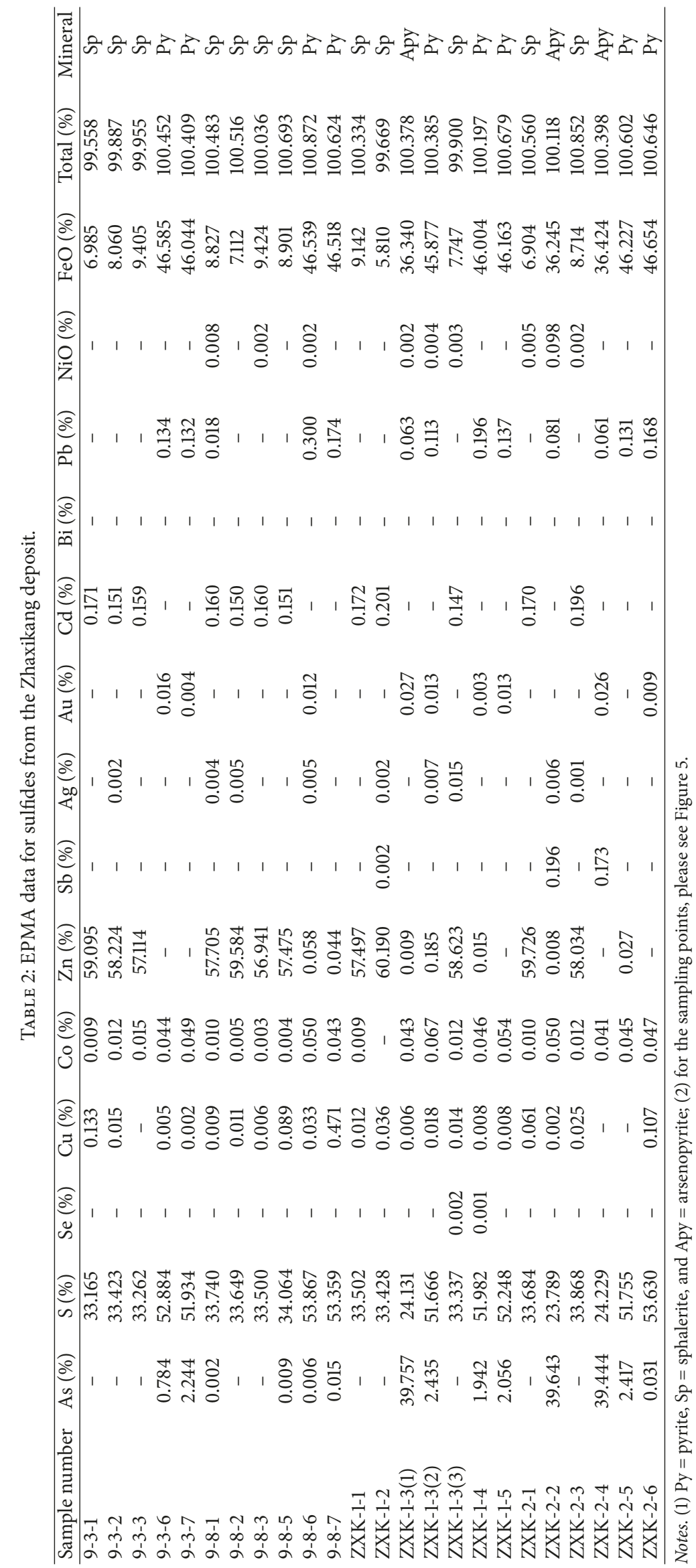




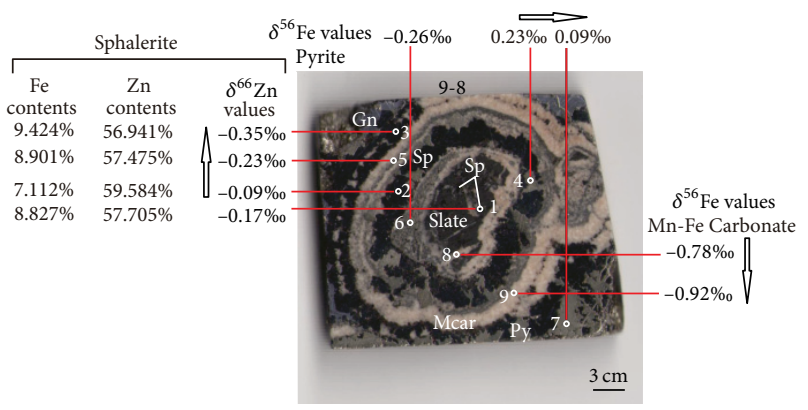

(a)

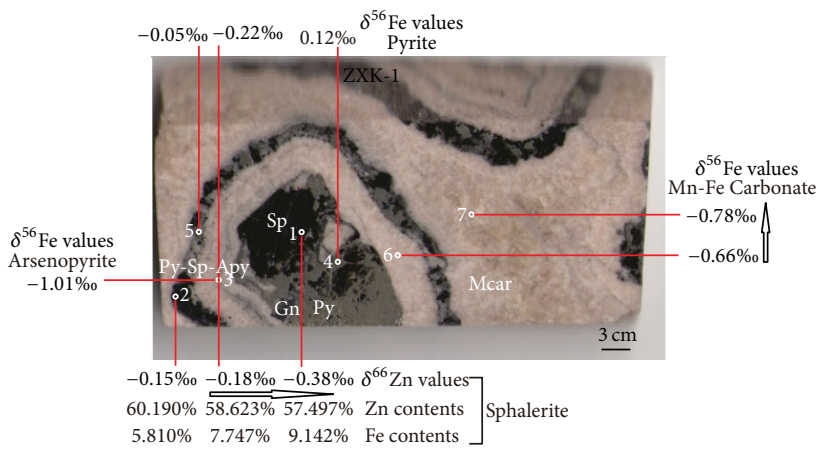

(c)

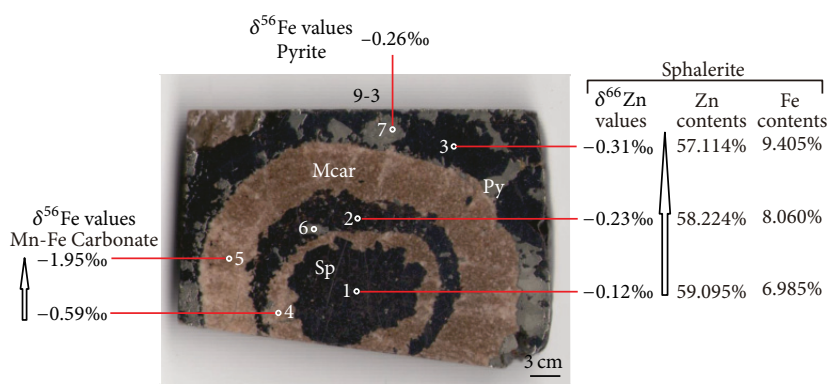

(b)

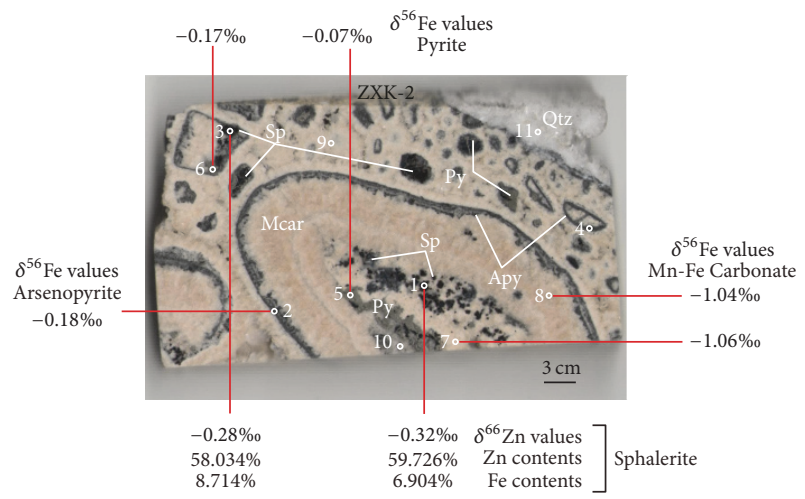

(d)

FIgURE 5: The sampling points and Fe-Zn isotopic-elemental variations in the annular polished section samples: (a) 9-8; (b) 9-3; (c) ZXK-1; (d) ZXK-2. Mcar = Mn-Fe carbonate; Apy = arsenopyrite; Py = pyrite; Sp = sphalerite; Qtz = quartz.

values of ZXK-1-3 (-0.18\%; Figures 6(f) and 6(m)) and ZXK1-2 $(-0.15 \%$; Figure $6(\mathrm{~g}))$ sphalerite are almost the same and heavier than ZXK-1-1 (-0.38\%o) sphalerite; the $\delta^{56} \mathrm{Fe}$ values for pyrite increase from ZXK-1-3 $(-0.22 \%$ ) to ZXK1-4 (0.12\%; Figure 6(e)) and ZXK-1-5 (-0.05\%o); and, as for Mn-Fe carbonate, the ZXK-1-6 $\left(-0.66 \%\right.$ ) has heavier $\delta^{56} \mathrm{Fe}$ values than ZXK-1-7 (-0.78\%o; Figure 5(c)). By contrast, in sample ZXK-2, the ZXK-2-1 (-0.32\%o; Figure 6(h)) and ZXK$2-3(-0.28 \%$; Figures $6(\mathrm{k})$ and $6(\mathrm{p}))$ sphalerite have almost the same $\delta^{66} \mathrm{Zn}$ values; the ZXK-2-7 (-1.06\%) and ZXK-2$8(-1.04 \%) \mathrm{Mn}-\mathrm{Fe}$ carbonate also yield approximate $\delta^{56} \mathrm{Fe}$ values; also the ZXK-2-5 (Figures 6(i) and 6(n)) and ZXK-26 pyrite show the similar $\delta^{56} \mathrm{Fe}$ values of $-0.07 \%$ and $-0.17 \%$ o (Figure 5(d)).

\section{Discussion}

5.1. The Fe-Zn Isotopic and Elemental Variations. Sample 93 with typical concentric annular texture has the gradually decreasing $\delta^{66} \mathrm{Zn}$ values of sphalerite and $\delta^{56} \mathrm{Fe}$ values of $\mathrm{Mn}$ $\mathrm{Fe}$ carbonate from core to edge (early to late; Figure 5(b)). Similarly, sample 9-8 shows the same isotopic variation trend of pyrite, sphalerite, and Mn-Fe carbonate except the sulfides in the core (Figure 5(a)). As the core in 9-8 consists of crushed, earlier formed slate breccias and sulfides, the annular sulfides and $\mathrm{Mn}-\mathrm{Fe}$ carbonate formed around the core, and thus this core is not included in the decreasing trend. In sample ZXK-1, as the laminae (ZXK-1-3; Figure 5(c)) is regarded as the earliest, the Fe- $\mathrm{Zn}$ isotopic values of sphalerite and $\mathrm{Mn}$-Fe carbonate still present gradually decreasing trend from ZXK-1-3 (-0.18\%o) to ZXK-1-1 (-0.38\%o) and ZXK-1-6 $(-0.66 \%)$ to ZXK-1-7 $(-0.78 \%$ ), respectively (Figure $5(\mathrm{c})$ ), whereas the $\delta^{56} \mathrm{Fe}$ values of pyrite show the different variation, which might be related to the influence of Fe isotopic fractionation within pyrite-arsenopyrite-sphalerite mineral pair (Figures 6(f) and 6(m)). However, there is no similar decreasing $\mathrm{Fe}-\mathrm{Zn}$ isotopic variation trend in sample ZXK-2, and the modification by the stage 3 quartz vein must be the main cause (Figures 5(d), 6(h)-6(l) and 6(n)-6(p)).

Previous studies [12, 62, 99] have proposed a Rayleigh distillation model to explain an increasing trend in $\delta^{66} \mathrm{Zn}$ values within precipitates over time for the hydrothermal fluid. This Rayleigh distillation model is as follows: the oreforming materials derived from a single source would be subjected to kinetic Rayleigh fractionation that would lead to the early formed mineral precipitants being preferentially enriched in light isotopes, as well as residual fluids and later precipitants with heavier isotopic values, causing an increasing trend in isotopic values within precipitants over time. Several previous studies have used this distillation model to explain the $\mathrm{Zn}$ isotopic variation within different types of deposits (e.g., VHMS: [18]; Irish-type: [19, 100]; SEDEX: [20,53]). Likewise, this Rayleigh distillation model is also applicable to the $\mathrm{Fe}$ isotopic variation in skarn deposits $[21,22]$. However, the $\delta^{66} \mathrm{Zn}$ and $\delta^{56} \mathrm{Fe}$ values gradually decrease from early to late stages within Zhaxikang deposit, which cannot be explained by this distillation model. Another Rayleigh distillation mechanism models this 


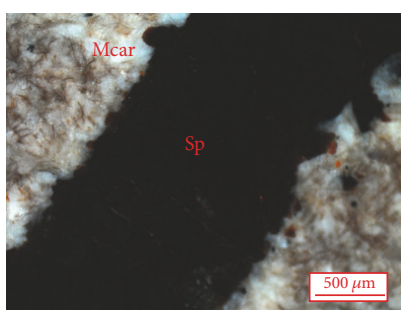

(a)

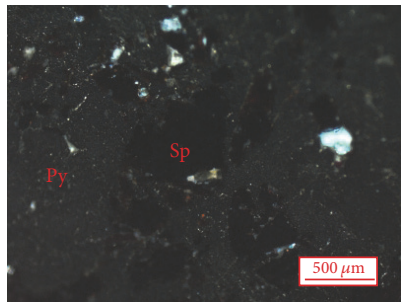

(e)

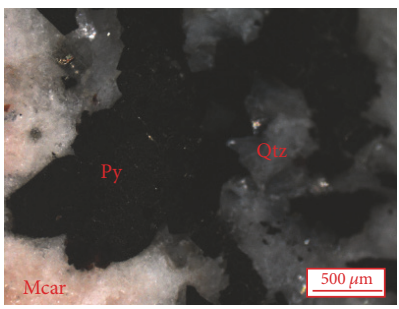

(i)

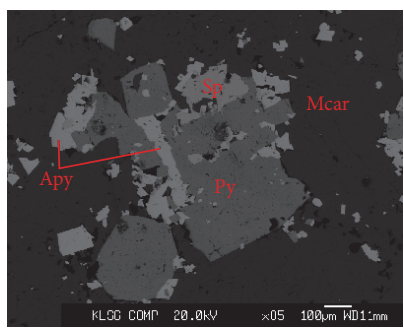

(m)

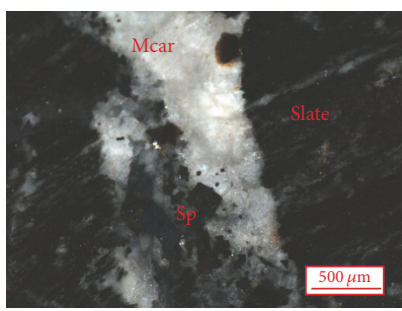

(b)

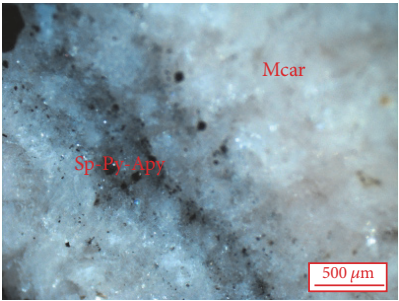

(f)

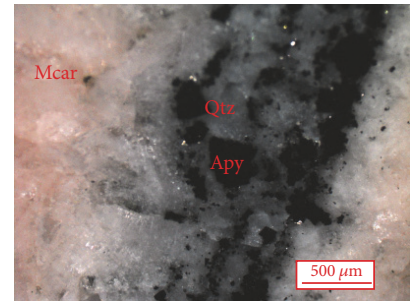

(j)

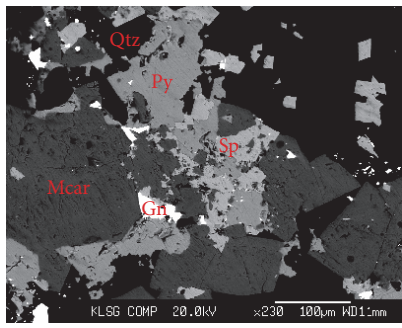

(n)

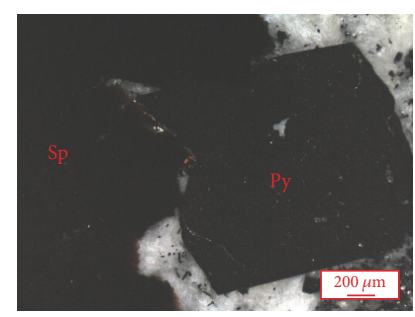

(c)

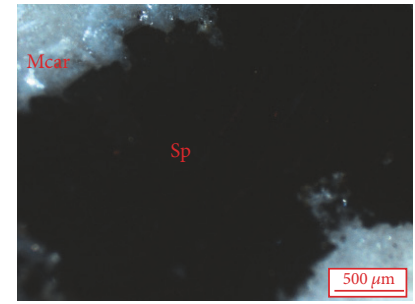

(g)

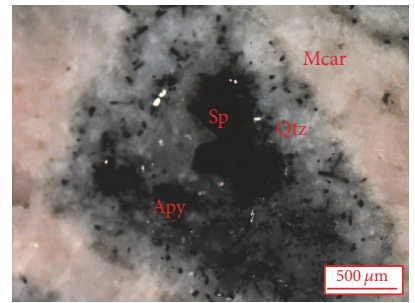

(k)

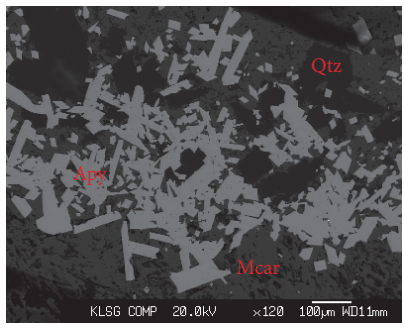

(o)

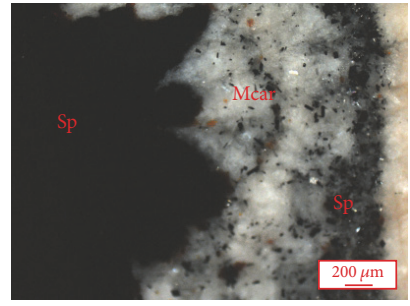

(d)

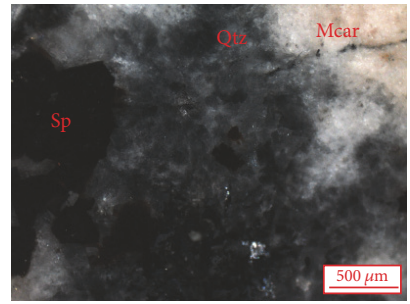

(h)

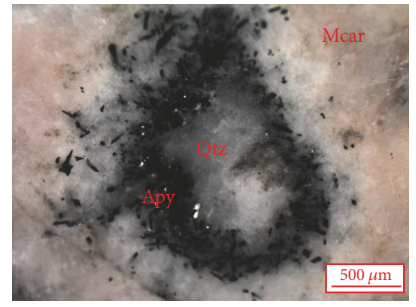

(1)

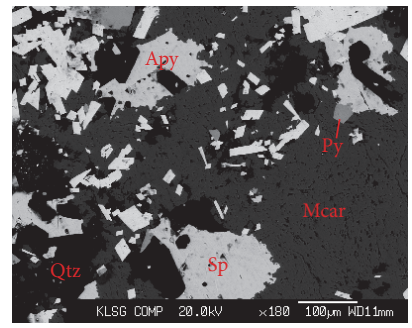

(p)

FIGURE 6: The photomicrographs and electron probe micrographs of sampling area in the annular polished section samples for EPMA and Fe-Zn isotopic analyses. (a) 9-3-2; (b) 9-8-8; (c) 9-8-2; (d) 9-8-3 and 9-8-5; (e) ZXK-1-4; (f) ZXK-1-3; (g) ZXK-1-2; (h) ZXK-2-1; (i) ZXK-2-5; (j) ZXK-2-2; (k) ZXK-2-3; (l) ZXK-2-4; (m) ZXK-1-3; (n) ZXK-2-5; (o) ZXK-2-2; (p) ZXK-2-3. Abbreviations are as in Figure 5.

decreasing trend: the metallogenic elements are transported by the ore-forming system consisting of vapour and liquid phases, and there is partitioning between vapour-liquid phases and the ratios change with the temperature decreasing. Then the minerals precipitate from the liquid phase of the ore-forming system. During this period, the vapour-liquid partitioning and mineral precipitation cause the Rayleigh fractionation, and this Rayleigh fractionation leads to the mineral precipitation being preferentially enriched in heavy isotopes relative to the ore-forming system. Thus, the isotopic values of subsequent minerals are lighter and lighter $[101,102]$.

This Rayleigh distillation model is supported by the following evidence: (1) The vapour-liquid partitioning and related isotopic fractionation for transition metal elements (e.g., $\mathrm{Cu}$ and $\mathrm{Mo}$ ) have been confirmed by previous research in the Dahutang W-Cu-Mo ore field [103]; (2) minerals typically precipitate from the liquid phase; however, according to the previous literature [58], in unique cases the vapour phase containing metal can even directly condensate to form solid phases from high-temperature ore-forming system (e.g., VMS and volcano related system), which can demonstrate the existence of the vapour phase for metal elements. As for the Zhaxikang deposit, the theoretical calculated oreforming temperature from $\mathrm{Fe}$ isotopic data is $500 \sim 800^{\circ} \mathrm{C}$ [26], and thus there should be a transitory high-temperature period, making the vapour-liquid partitioning possible; (3) the fluid inclusion data demonstrate that Mn-Fe carbonates and sulfides exist in three types of inclusions: (1) gas-liquid two-phase water inclusions (W type, more than 90\%), (2) pure 


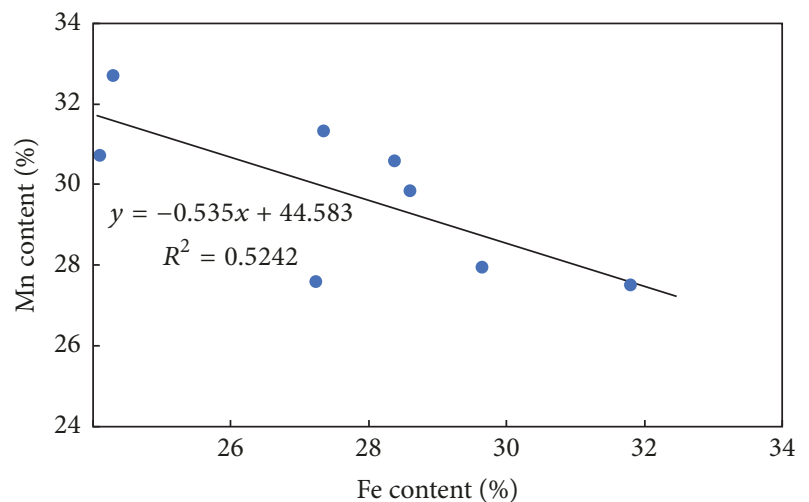

- Mn-Fe carbonate

(a)

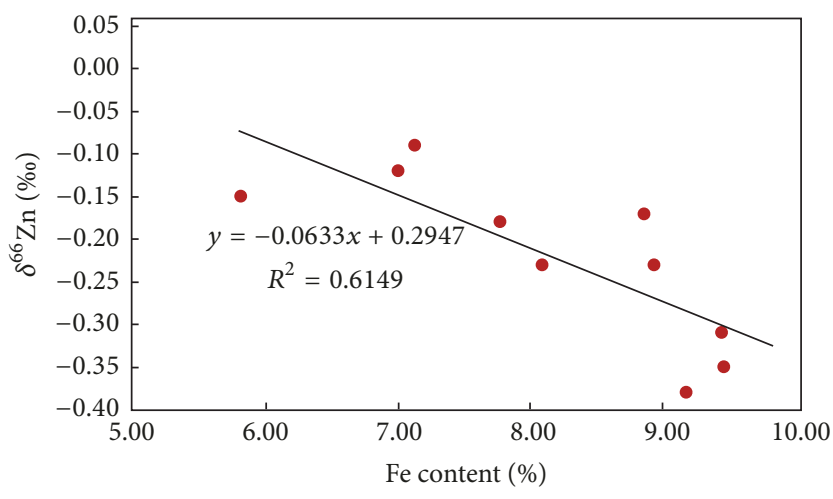

- Sphalerite

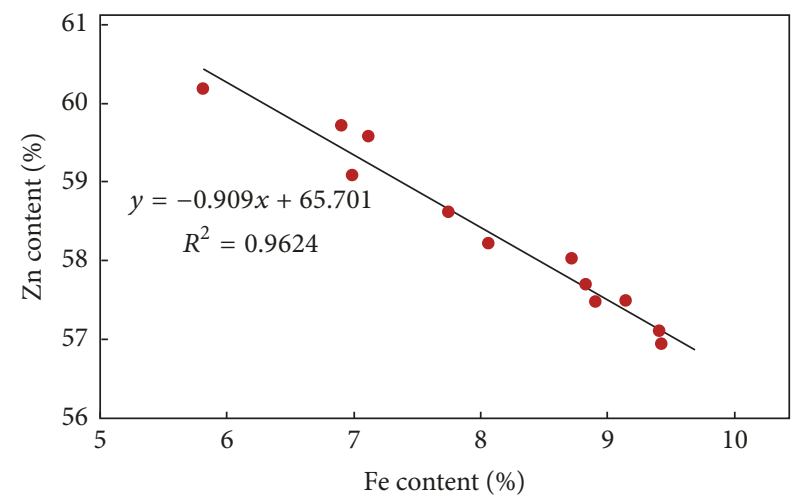

- Sphalerite

(b)

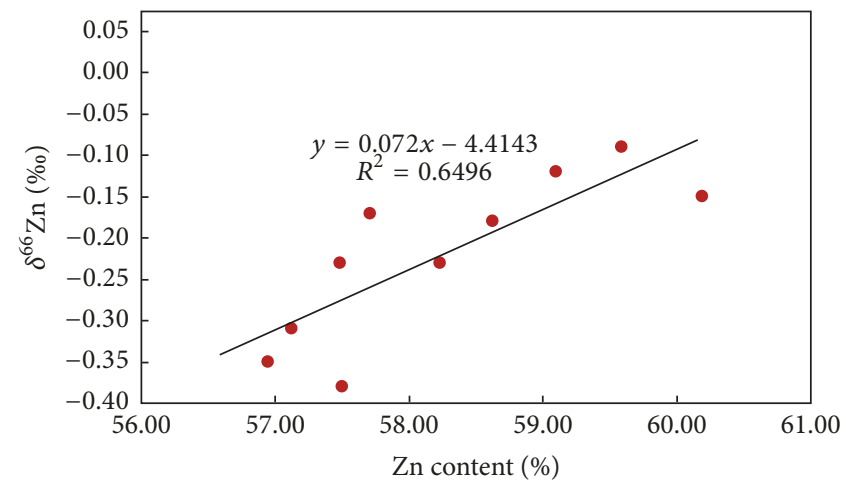

- Sphalerite

(d)

Figure 7: (a) The negative correlation between Mn and Fe contents within Mn-Fe carbonate. (b) The negative correlation between $\mathrm{Zn}$ and Fe contents within sphalerite. (c) The negative correlation between $\delta^{66} \mathrm{Zn}$ values and Fe contents within sphalerite from 9-3, 9-8, and ZXK-1. (d) The positive correlation between $\delta^{66} \mathrm{Zn}$ values and $\mathrm{Zn}$ contents within sphalerite from 9-3, 9-8, and ZXK-1.

liquid inclusions (L type), and (3) pure $\mathrm{CO}_{2}$ inclusions (PG type) [104] from Zhaxikang deposit.

On the other hand, for sphalerite, there are positive correlations between $\mathrm{Zn}$ contents and $\delta^{66} \mathrm{Zn}$ values, with negative correlations between Fe contents and $\delta^{66} \mathrm{Zn}$ values in samples 9-8 (Figure 5(a)), 9-3 (Figure 5(b)), and ZXK-1 (Figure 5(c)), respectively. Moreover, plotting all the data from these three samples on a diagram together, the correlations are also good with $R^{2}>0.6$ (Figures $7(\mathrm{c})$ and $7(\mathrm{~d})$ ). Zinc and iron usually show similar geochemical behaviour as both of them are highly mobile in chloride-bearing hydrothermal fluids $[23,100]$. Thus, the $\mathrm{Zn}^{2+}$ and $\mathrm{Fe}^{2+}$ ions are preferentially enriched in the liquid phase relative to the vapour phase before precipitation $[23,100]$, which cause the decreasing $\mathrm{Zn}$ contents of sphalerite over time. As the total content of $\mathrm{Zn}^{2+}$ and $\mathrm{Fe}^{2+}$ is constant in sphalerite, the Fe contents of sphalerite gradually increase with the decreasing $\mathrm{Zn}$ contents. These correlations further support the hypothesis that the oreforming system is the mixture of vapour and liquid phases. In addition, the sample ZXK-2 cut by a later stage 3 quartz vein does not present the same correlations and variations, which is a new evidence for two pulses of mineralization proposed by Zheng et al. [7] and Wang et al. [26].
All of the evidence above reveals that the ore-forming elements are transported by the ore-forming system that consists of vapour and liquid phases. The vapour-liquid partitioning and mineral precipitation are the main cause of Fe- $\mathrm{Zn}$ isotopic and elemental variations. Afterwards, the overprint by the second pulse of mineralization has also partly modified the $\mathrm{Fe}-\mathrm{Zn}$ isotopic and elemental compositions of some earlier samples (Figure 5(d)) [26].

5.2. The Fe-Zn Isotopic Fractionation Models for the OreForming System. In order to verify the Rayleigh distillation model in Section 5.1 and obtain more information of the oreforming system, we use the following equations to establish $\mathrm{Fe}-\mathrm{Zn}$ isotopic fractionation models for the ore-forming system and mineral precipitation:

$$
\begin{aligned}
\delta_{\text {Minerals }}(\%)= & \frac{\alpha}{\alpha_{i}} \times\left(\delta_{i}+1000\right) \times F^{\left(\alpha_{m}-1\right)} \\
& -1000, \\
\delta_{\text {Ore-forming System }}(\% 0)= & \frac{1}{\alpha_{i}} \times\left(\delta_{i}+1000\right) \times F^{\left(\alpha_{m}-1\right)} \\
& -1000 .
\end{aligned}
$$


TABLE 3: Fe-Zn isotopic data for annular polished section samples from the Zhaxikang deposit.

\begin{tabular}{|c|c|c|c|c|c|}
\hline Sample number & Mineral & $\delta^{56} \mathrm{Fe}_{\text {IRMM-014 }}$ & $2 \sigma$ & $\delta^{66} \mathrm{Zn}_{\mathrm{AA}-\mathrm{ETH}}$ & $2 \sigma$ \\
\hline $9-3-1$ & Sp & & & -0.12 & 0.05 \\
\hline $9-3-2$ & Sp & & & -0.23 & 0.05 \\
\hline $9-3-3$ & Sp & & & -0.31 & 0.05 \\
\hline $9-3-4$ & Mcar & -0.59 & 0.08 & & \\
\hline $9-3-5$ & Mcar & -1.95 & 0.08 & & \\
\hline $9-3-7$ & Py & -0.26 & 0.08 & & \\
\hline $9-8-1$ & Sp & & & -0.17 & 0.05 \\
\hline $9-8-2$ & Sp & & & -0.09 & 0.05 \\
\hline $9-8-3$ & Sp & & & -0.35 & 0.05 \\
\hline $9-8-4$ & Py & 0.23 & 0.08 & & \\
\hline $9-8-5$ & Sp & & & -0.23 & 0.05 \\
\hline $9-8-6$ & Py & -0.26 & 0.08 & & \\
\hline $9-8-7$ & Py & 0.09 & 0.08 & & \\
\hline $9-8-8$ & Mcar & -0.78 & 0.08 & & \\
\hline $9-8-9$ & Mcar & -0.92 & 0.08 & & \\
\hline ZXK-1-1 & Sp & & & -0.38 & 0.05 \\
\hline ZXK-1-2 & Sp & & & -0.15 & 0.05 \\
\hline ZXK-1-3(1) & Apy & -1.01 & 0.08 & & \\
\hline ZXK-1-3(2) & Py & -0.22 & 0.08 & & \\
\hline ZXK-1-3(3) & Sp & & & -0.18 & 0.05 \\
\hline ZXK-1-4 & Py & 0.12 & 0.08 & & \\
\hline ZXK-1-5 & Py & -0.05 & 0.08 & & \\
\hline ZXK-1-6 & Mcar & -0.66 & 0.09 & & \\
\hline ZXK-1-7 & Mcar & -0.78 & 0.08 & & \\
\hline ZXK-2-1 & Sp & & & -0.32 & 0.05 \\
\hline ZXK-2-2 & Apy & -0.18 & 0.08 & & \\
\hline ZXK-2-3 & Sp & & & -0.28 & 0.05 \\
\hline ZXK-2-5 & Py & -0.07 & 0.08 & & \\
\hline ZXK-2-6 & Py & -0.17 & 0.08 & & \\
\hline ZXK-2-7 & Mcar & -1.06 & 0.08 & & \\
\hline ZXK-2-8 & Mcar & -1.04 & 0.08 & & \\
\hline
\end{tabular}

Notes. (1) Abbreviations and sampling points are as in Tables 1 and 2; (2) $2 \sigma$ is two times the standard deviation.

$\delta_{\text {Minerals }}, \delta_{\text {Ore-forming System }}$, and $\delta_{i}$ are the $\delta^{56} \mathrm{Fe}-\delta^{66} \mathrm{Zn}$ values of momentary mineral precipitation and momentary and initial ore-forming system, respectively; $\alpha, \alpha_{i}$, and $\alpha_{m}$ are the isotopic fractionation factors between ore-forming system and mineral precipitation that refer to the momentary condensation temperature $T$, the initial temperature of oreforming system $T_{i}$, and $\left(T+T_{i}\right) / 2$, respectively; and $F$ is the fraction of remaining ore-forming system that consists of vapour and liquid phases [102, 105]. In addition, the equations for fractionation factors are approximately using $\ln \alpha_{\mathrm{Fe}}=0.4432 \times 10^{6} / T^{2}$ for Fe [106] and $\ln \alpha_{\mathrm{Zn}}=0.2853 \times$ $10^{6} / T^{2}+0.0535$ for $\mathrm{Zn}(T$ is absolute temperature in $\mathrm{K}$ ) [107].

Wang et al. [26] have calculated the ore-forming temperature $\left(500 \sim 800^{\circ} \mathrm{C}\right)$ of the first pulse of mineralization in Zhaxikang deposit using the $\mathrm{Fe}$ isotopic fractionation between pyrite and $\mathrm{Mn}-\mathrm{Fe}$ carbonate. Although this temperature range is a little wide, the highest temperature of such ore-forming system can reach around $500^{\circ} \mathrm{C}$ according to the previous ore deposit studies $[6,22,23]$; hence we regard $500^{\circ} \mathrm{C}$ as the initial temperature of the ore-forming system. The homogenization temperature $\left(240^{\circ} \mathrm{C}\right)$ of the fluid inclusions [104] from the first pulse of mineralization in Zhaxikang deposit is considered as the momentary condensation temperature. Furthermore, for the purpose of making the fractionation models more comprehensive and exact, we also quote the $\mathrm{Fe}-\mathrm{Zn}$ isotopic data of pyrite $\left(\delta^{56} \mathrm{Fe}\right.$ : stage 1: $-0.33 \%$ o to $-0.09 \%$; stage 2 : $-0.30 \%$ o to $0.19 \%$; stage 3 : $0.16 \%$ o to $0.43 \%$ ), sphalerite $\left(\delta^{66} \mathrm{Zn}\right.$ : $-0.31 \%$ o to $0.07 \%$ o), and $\mathrm{Mn}-\mathrm{Fe}$ carbonate $\left(\delta^{56} \mathrm{Fe}:-0.80 \%\right.$ o to $-0.55 \%$; $\delta^{66} \mathrm{Zn}$ : $-0.11 \%$ o to $0.04 \%$ ) from Wang et al. [26], as well as the $\delta^{66} \mathrm{Zn}$ values of sphalerite $(-0.25 \%$ to $0.03 \%$ o $)$ and $\mathrm{Mn}$-Fe carbonate $(-0.01 \%$ ) from Duan et al. [5]. Finally, we set up $12 \mathrm{Fe}-$ $\mathrm{Zn}$ isotopic fractionation models for pyrite, sphalerite, and $\mathrm{Mn}-\mathrm{Fe}$ carbonate (Figure 8) with different $\delta^{56} \mathrm{Fe}_{i}$ values of $0 \%$ (mean value of magma) [51], $-0.5 \%$, and $-1 \%$, as well as $\delta^{66} \mathrm{Zn}_{i}$ values of $-0.28 \%$ o (the lightest value of seafloor hydrothermal fluids) [62], 0\%o (mean value of bulk earth) 


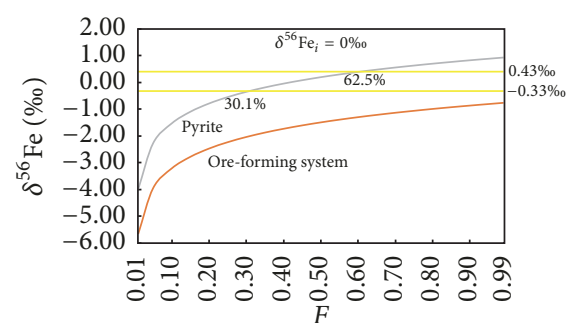

(a)

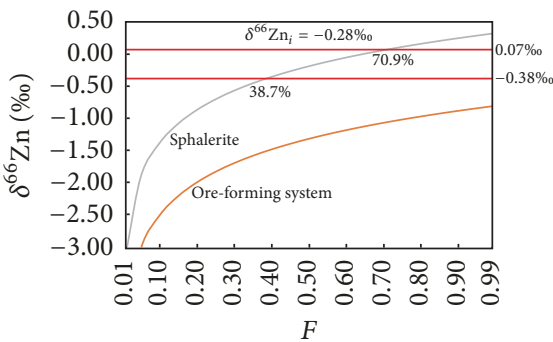

(d)

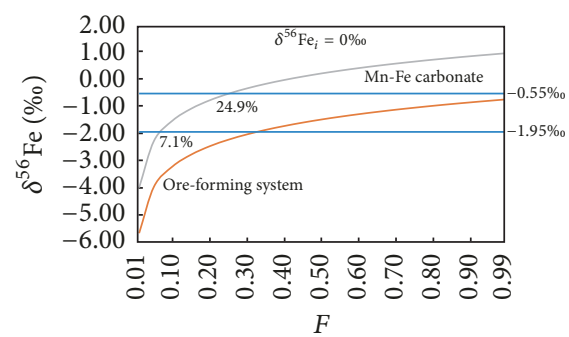

(g)

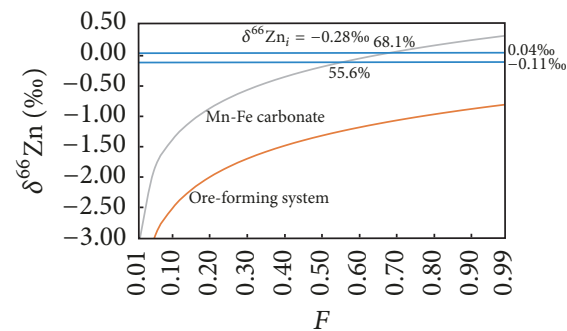

(j)

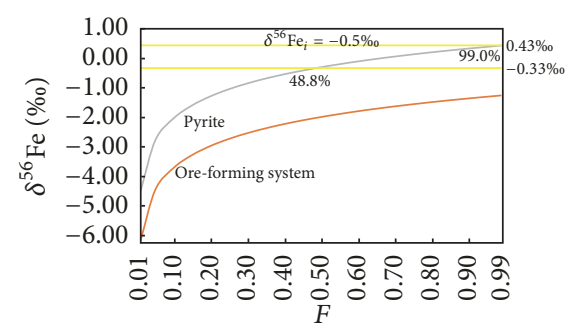

(b)

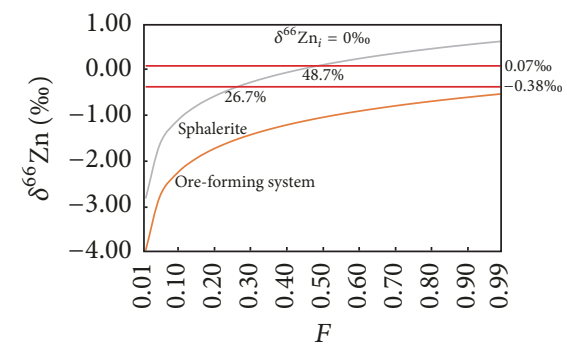

(e)

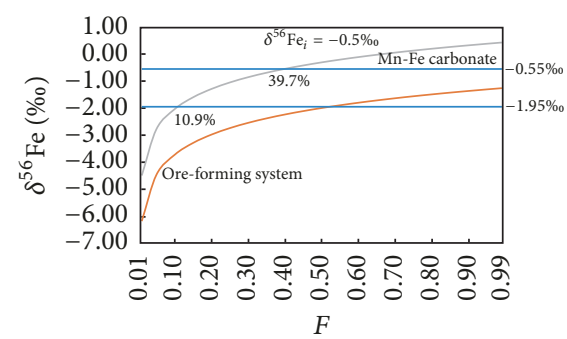

(h)

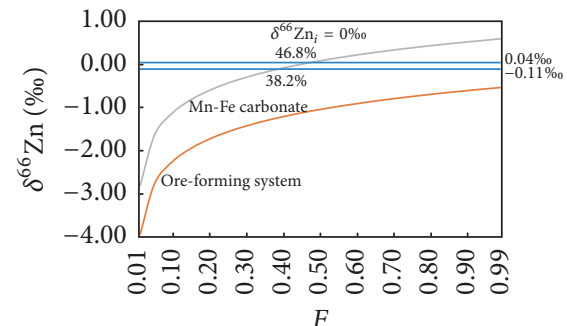

(k)

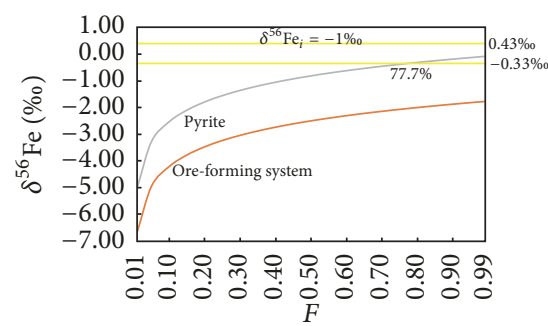

(c)

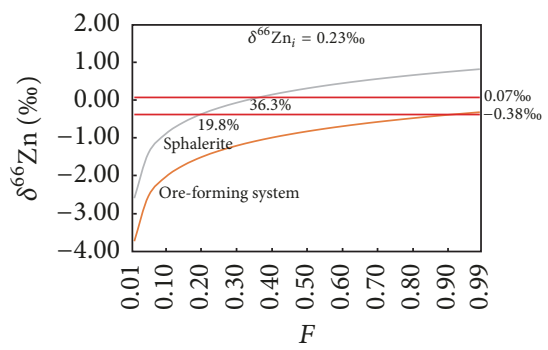

(f)

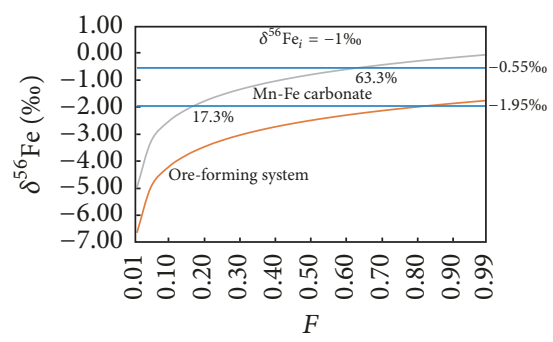

(i)

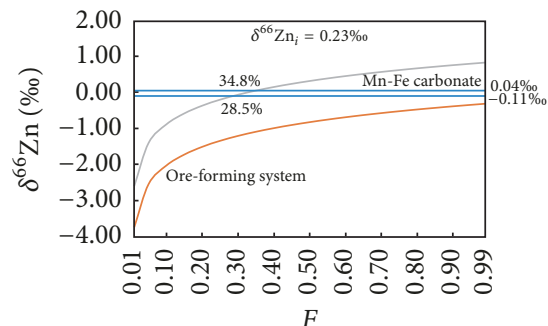

(1)

FIGURE 8: The Fe- $\mathrm{Zn}$ isotopic fractionation models for the ore-forming system and minerals (pyrite, sphalerite, and Mn-Fe carbonate) with different $\delta^{56} \mathrm{Fe}_{i}$ and $\delta^{66} \mathrm{Zn}_{i}$ values.

[54], and $0.23 \%$ o (the mean value of deep sea water) $[63,108$, 109].

These fractionation models show that the $F$ ranges for ore-forming system highly depend on the $\delta_{i}$ values (Figure 8). The details are as follows: the pyrite covers the $F$ ranges of $30.1 \% \sim 62.5 \%\left(\delta^{56} \mathrm{Fe}_{i}=0 \%\right.$; Figure $\left.8(\mathrm{a})\right), 48.8 \% \sim 99.0 \%$ $\left(\delta^{56} \mathrm{Fe}_{i}=-0.5 \%\right.$; Figure $\left.8(\mathrm{~b})\right)$, and more than $77.7 \%\left(\delta^{56} \mathrm{Fe}_{i}\right.$ $=-1 \%$; Figure $8(\mathrm{c}))$. The $F$ ranges for sphalerite are $38.7 \% \sim 70.9 \%\left(\delta^{66} \mathrm{Zn}_{i}=-0.28 \%\right.$; Figure $\left.8(\mathrm{~d})\right), 26.7 \% \sim 48.7 \%$ $\left(\delta^{66} \mathrm{Zn}_{i}=0 \%\right.$; Figure $\left.8(\mathrm{e})\right)$, and $19.8 \% \sim 36.3 \%\left(\delta^{66} \mathrm{Zn}_{i}=\right.$ $0.23 \%$; Figure $8(\mathrm{f}))$, respectively. In comparison, the $\mathrm{Mn}-\mathrm{Fe}$ carbonates has the $F$ ranges of $7.1 \% \sim 24.9 \%\left(\delta^{56} \mathrm{Fe}_{i}=0 \%\right.$; Figure $8(\mathrm{~g}))$, $10.9 \% \sim 39.7 \%\left(\delta^{56} \mathrm{Fe}_{i}=-0.5 \%\right.$; Figure $\left.8(\mathrm{~h})\right)$, and $17.3 \% \sim 63.3 \%\left(\delta^{56} \mathrm{Fe}_{i}=-1 \%\right.$; Figure $\left.8(\mathrm{i})\right)$ for Fe isotope, as well as $55.6 \% \sim 68.1 \%\left(\delta^{66} \mathrm{Zn}_{i}=-0.28 \%\right.$; Figure $\left.8(\mathrm{j})\right)$, $38.2 \% \sim 46.8 \%\left(\delta^{66} \mathrm{Zn}_{i}=0 \%\right.$; Figure $\left.8(\mathrm{k})\right)$, and $28.5 \% \sim 34.8 \%$ $\left(\delta^{66} \mathrm{Zn}_{i}=0.23 \%\right.$; Figure $\left.8(1)\right)$ for $\mathrm{Zn}$ isotope. All of these results suggest that the $\mathrm{Fe}-\mathrm{Zn}$ isotopic data of Zhaxikang deposit fit these Rayleigh fractionation models well.

However, we need to consider the following facts in the Zhaxikang deposit: (1) the second pulse of mineralization has brought some Fe to form the stage 3 pyrite with heavier $\delta^{56} \mathrm{Fe}$ values $\left(0.23 \%{ }_{0} \sim 0.43 \%\right.$ o $)[26]$; thus the stage 3 pyrite does not fit the fractionation models; (2) as most of the sphalerite and pyrite are paragenetic during the first pulse of mineralization (Figures 4(g), 4(i), 4(k), 5(a)-5(c) and 6(c)), especially in the earliest lamina (Figures 4(a)-4(c), 5(c), 6(f) and $6(\mathrm{~m}))$, the sphalerite and pyrite should overlap on $F$ 
ranges; (3) in theory, the $\mathrm{Mn}-\mathrm{Fe}$ carbonates would have the same $F$ range for Fe- $\mathrm{Zn}$ isotopes. Nonetheless, in view of the tight $\mathrm{Zn}$ isotopic variation range, the $F$ range for $\mathrm{Fe}$ isotope should cover that for $\mathrm{Zn}$ isotope; (4) during the earlier period, as the ore-forming system consisting of vapour and liquid phases is dominant, $F$ values in fractionation models should be large. Taking all these facts and 12 fractionation models into consideration, the $\delta^{56} \mathrm{Fe}_{i}$ value is supposed to be in the range of $-0.5 \%$ o $-1 \%$, and the $\delta^{66} \mathrm{Zn}_{i}$ value should be between $-0.28 \%$ and $0 \%$.

\subsection{Implications for the Genesis of Zhaxikang Deposit}

5.3.1. Excluding the Possibility of Hot Spring Genetic Model. The hot spring model predicts that metals (e.g., Zn, $\mathrm{Pb}, \mathrm{Sb}, \mathrm{Ag}$, and $\mathrm{Fe}$ ) are leached from sedimentary wall rocks, which is supported by the following evidence: (1) the $\delta^{34} \mathrm{~S}$ values of the sulfides $\left(4.5 \%{ }^{\circ} \sim 12 \%\right.$ ) are similar to those of sedimentary wall rocks $(4.93 \%$ o $11.49 \%$ ); (2) the $\delta^{30} \mathrm{Si}$ values of quartz $(-0.90 \%$ $-0.40 \%$ o $)$ are the same as those of siliceous rocks with hot spring genesis; (3) the $\delta \mathrm{D}_{\mathrm{V}-\mathrm{SMOW}}(-135 \% 0 \sim-127 \%$ o $)$ and $\delta^{18} \mathrm{O}_{\mathrm{H}_{2} \mathrm{O}}$ values $(-13.7 \% 0 \sim 12.4 \%$ o $)$ of fluid inclusions trapped in quartz are similar to those of the south Tibetan hot spring; (4) the $\mathrm{Pb}$ isotopes $\left({ }^{206} \mathrm{~Pb} /{ }^{204} \mathrm{~Pb}: 18.474 \sim 19.637 ;{ }^{207} \mathrm{~Pb} /{ }^{204} \mathrm{~Pb}: 15.649 \sim\right.$ $\left.15.774 ;{ }^{208} \mathrm{~Pb} /{ }^{204} \mathrm{~Pb}: 39.660 \sim 40.010\right)$ show the characteristics of radiogenic $\mathrm{Pb}$; (5) the $\mathrm{He}-\mathrm{Ar}$ isotopes demonstrate the contribution of crustal fluid and meteoric water $[3,4]$.

However, this genetic model is inconsistent with textural and $\mathrm{Fe}-\mathrm{Zn}$ isotopic evidence presented here. Firstly, the primary sedimentary wall rocks in the orefield are slate. As suggested by the continuous batch experimental research of Fernandez and Borrok [27], the ore-forming fluid would preferentially leach out the heavy $\mathrm{Zn}$ isotopes. Likewise, Chen et al. [110] have analyzed the $\mathrm{Zn}$ isotopic compositions of samples from 8 hot springs, and the results show most of the hot springs have relatively constant and heavier $\delta^{66} \mathrm{Zn}$ values (approximately $0.42 \%$ o) than host rocks $(-0.42 \%$ o to $0.14 \%$ ). Therefore, if the metallogenic elements are leached from the slate by hot spring, there would be some sphalerite with heavier $\delta^{66} \mathrm{Zn}$ values than these slates in Zhaxikang deposit. Nevertheless, the $\delta^{66} \mathrm{Zn}$ values of the slate from Zhaxikang orefield range from $-0.23 \%$ to $0.10 \%$ o that are similar to sphalerite, especially the unmodified slate sample with the $\delta^{66} \mathrm{Zn}$ value of $0.10 \%$ o that is even a little heavier than that of sphalerite (-0.38\%o to $0.07 \%$; Figure $9(\mathrm{~b}))$ [26]. As the slate has heavier $\mathrm{Zn}$ isotopic compositions than those of host rocks from Chen et al. [110], the $\delta^{66} \mathrm{Zn}$ values of the hot spring in Zhaxikang orefield would even be heavier than $0.42 \%$, which are much heavier than the $\delta^{66} \mathrm{Zn}_{i}$ values $(-0.28 \% 0 \sim 0 \%$ o) of the fractionation models in Section 5.2. Secondly, Sharam et al. [46] have measured the $\delta^{56} \mathrm{Fe}$ values ( $-0.59 \%$ o to $-0.12 \%$ ) of hot springs in Juan de Fuca Ridge, which is much heavier than the $\delta^{56} \mathrm{Fe}_{i}$ value $(-0.5 \%$ o $-1 \%$ ) gained from the fractionation models. Moreover, the marine fluids usually have lighter Fe isotopic compositions (Figure 9(a)); thus the hot springs in Tibet would have heavier $\delta^{56} \mathrm{Fe}$ values than those of Sharam et al. [46].
The possibility of hot spring genesis for the first pulse of mineralization event can be excluded by $\mathrm{Fe}-\mathrm{Zn}$ isotopic data. Evidence for the second pulse of mineralization is based on the fact that the $\mathrm{Fe}-\mathrm{Zn}$ isotope values do not follow similar concentric patterns with the ore textures as seen in sample ZXK-2. Meanwhile, the evidence from Si-H-O isotopes demonstrates that the second pulse of mineralization may be related to hot spring. Additionally, the Fe- $\mathrm{Zn}$ isotopic data demonstrate that the sedimentary wall rocks have not provided significant amounts of metals, although the $\mathrm{S}-\mathrm{Pb}$ isotopic data show that these wall rocks constitute some contribution for $\mathrm{S}-\mathrm{Pb}[4,5]$, whereas the similar $\mathrm{Zn}$ isotopic compositions of slate and sphalerite suggest that they share the same $\mathrm{Zn}$ origin.

\subsubsection{Inconsistency with the Magmatic-Hydrothermal Fluid} Genetic Models. There are two genetic models for the magmatic-hydrothermal fluid genesis. In the first model, Duan et al. [5] considered that the genesis of Zhaxikang deposit relates to the mid-low temperature magma-related hydrothermal activity and that the metallogenic elements are mainly sourced from the mixing of basement and the sedimentary wall rocks. The evidence is mainly from the $\mathrm{Zn}$ $\mathrm{S}-\mathrm{Pb}$ isotopes that we mentioned in Section 1.

Duan et al. [5] have analyzed the $\delta^{66} \mathrm{Zn}$ values of the sulfides $(-0.25 \%$ 0.03\%o) and basement rocks $(0.05 \%$ $0.21 \%$ ). The dominating sedimentary wall rocks in the orefield are slate ( $\delta^{66} \mathrm{Zn}$ values: $-0.23 \%$ $~ 0.10 \%$ ) [26], which is formed by the epimetamorphism of shale and sandstone. Meanwhile, combining the data from Wang et al. [26] with this study, the sphalerite should have a range from $-0.38 \%$ o to $0.07 \%$ in Zhaxikang deposit. Both the basement and sedimentary wall rocks have heavier $\mathrm{Zn}$ isotopic compositions than sphalerite in Zhaxikang deposit. However, just like we discussed in Section 5.3.1, if the $\mathrm{Zn}$ is sourced from mixing of the basement and sedimentary wall rocks, there should be some sphalerite with heavier $\delta^{66} \mathrm{Zn}$ values than these rocks. This inference is also evidenced by the research of Zhou et al. [64]: the Paleozoic carbonate host rocks and Precambrian basements are considered to be the origin of metals, and these rocks have lighter $\delta^{66} \mathrm{Zn}$ values $(-0.52 \%$ o to $0.16 \%$ ) than the sphalerite from the Tianqiao $(-0.54 \%$ o to $0.30 \%$ ) and Bangbangqiao ( $-0.21 \%$ o to $0.43 \%$ ) deposits in the Sichuan-Yunnan-Guizhou $\mathrm{Pb}-\mathrm{Zn}$ metallogenic province (Figure 9(b)). Additionally, in respect of the Fe isotope, the Schwarzwald hydrothermal vein deposit in Germany can be used as an analogy [52]. Iron in this deposit originates from the basement consisting of granites and gneisses, as well as sedimentary rocks including shale and sandstone. The basement of Zhaxikang is composed of dolerite, quartz diorite, rhyolite porphyry, pyroclastics, and porphyritic monzogranite [5], and these crust-derived igneous rocks have the similar Fe isotopic composition with granites according to the data from previous studies [21-23, 28, 36-45]. Likewise, the $\delta^{56} \mathrm{Fe}$ values of shale and sandstone in the Schwarzwald deposit are $-0.21 \%$ o $0.03 \%$, and $0.22 \%$, all of which fall into the $\mathrm{Fe}$ isotopic variation range of shale $(-0.39 \% 0 \sim 0.71 \%$ ) from Beard et al. [34] and Rouxel et al. [35]. Therefore, we 


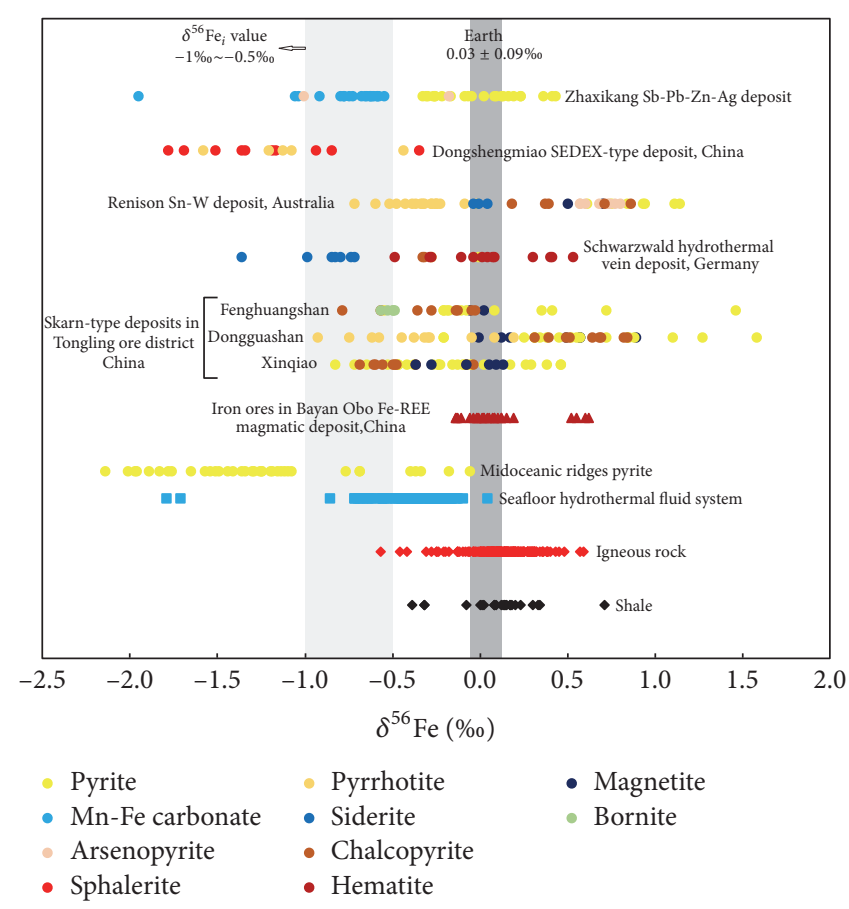

(a)

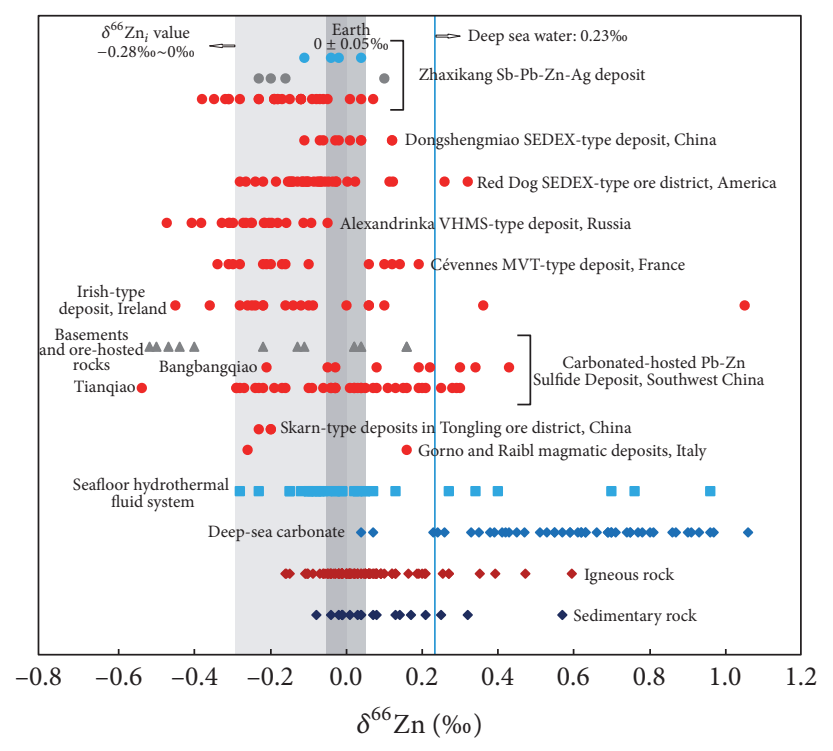

- Mn-Fe carbonate

- Sphalerite

- Slate

FIGURE 9: (a) Fe isotopic compositions of pyrite, Mn-Fe carbonate, and arsenopyrite in the Zhaxikang deposit (part of the data is quoted from Wang et al. [26]). Other Fe isotopic data for the Bulk Silicate Earth [10], shale [34, 35], igneous rocks [21-23, 28, 36-45], seafloor hydrothermal fluid system [34, 46-49], midoceanic ridges pyrite [48, 50], the Bayan Obo Fe-REE magmatic-type deposit in China [51], the skarn-type deposits in Tongling ore district in China [21, 22], the Schwarzwald hydrothermal vein deposit in Germany [52], the Renison Sn-W deposit in Australia [23], and the Dongshengmiao SEDEX-type deposit in China [53] are also plotted for comparison. (b) Zn isotopic compositions of sphalerite, Mn-Fe carbonate, and slate in the Zhaxikang deposit (part of the data is quoted from Wang et al. [26]), compared with the Bulk Silicate Earth [54], sedimentary rocks [55-57], igneous rocks [28, 54, 57-60], deep-sea carbonates [61], seafloor hydrothermal fluid system [62], deep sea water [51, 54, 63], and other deposits with different geneses: the Gorno and Raibl magmatic-type deposit in Italy [14], the skarn-type deposits in the Tongling ore district in China [12], the Tianqiao and Bangbangqiao carbonated-hosted Pb-Zn sulfide deposits in China [64], the Irish-type deposit in Ireland [19], the Cévennes MVT deposit in France [65], the Alexandrinka VHMS-type deposit in Russia [18], the Red Dog SEDEX-type ore district in Alaska [20], and the Dongshengmiao SEDEX-type deposit in China [53].

regard the fact that the metal-sourced rocks in these two deposits have the similar Fe isotopic compositions. And, yet, Markl et al. [52] suggested that fluid-rock interaction make the ore-forming fluid have the $\delta^{56} \mathrm{Fe}$ value of $-0.5 \%$ $0 \%$, which is heavier than the $\delta^{56} \mathrm{Fe}_{i}$ value $(-0.5 \%$ $~-1 \%$ o $)$ of the fractionation models in Section 5.2. Furthermore, it is generally known that the equilibrium isotope fractionation is a function of temperature, with larger fractionation generated at lower temperatures [111]. Although the temperature of oreforming fluid $\left(100 \sim 200^{\circ} \mathrm{C}\right)$ [52] in the Schwarzwald deposit is lower than that in Zhaxikang deposit $\left(\sim 250^{\circ} \mathrm{C}\right)$ [5], the lightest $\delta^{56} \mathrm{Fe}$ value $(-1.36 \%)$ of siderite from this deposit is much heavier than that of $\mathrm{Mn}-\mathrm{Fe}$ carbonate $(-1.95 \%$ ) from Zhaxikang deposit (Figure 9(a)). All of these inconsistencies from $\mathrm{Fe}-\mathrm{Zn}$ isotopic data indicate that this genetic model is not appropriate for Zhaxikang deposit.

In the second genetic model, Xie et al. [6] suggested the mineralization in Zhaxikang deposit was genetically related to the Miocene dome-related magmatism. This magmatism generated the pegmatite and two-mica granite in the core of the regional domes (Figure 1(b); e.g., Cuonadong,
Yalaxiangbo, Ranba, and Kangma), and the high-temperature ore-forming fluids were derived from magmatic melts exsolution. This hypothesis is based on the research of field geology, petrography, melt and fluid inclusions, and $\mathrm{C}-\mathrm{H}-\mathrm{O}$ isotopes: (1) the $\delta^{13} \mathrm{C}_{\mathrm{V}-\mathrm{PDB}}\left(-6.1 \%\right.$ $~-6.9 \%$ ) and $\delta^{18} \mathrm{O}_{\mathrm{V}-\mathrm{SMOW}}$ $(+9.9 \%$ +11.8\%o) values of rhodochrosite show the manthe origin; (2) the $\delta^{13} \mathrm{D}_{\mathrm{V}-\mathrm{SMOW}}(-144.8 \% \sim-110 \%$ ) and $\delta^{18} \mathrm{O}_{\mathrm{V}-\mathrm{SMOW}}(-9.85 \%$ o $-8.89 \%$ o $)$ values, the low salinity (0.2 7.9 wt.\% NaCleqv), high temperature $\left(298 \sim 457^{\circ} \mathrm{C}\right)$, and rich $\mathrm{CO}_{2}$ content with minor $\mathrm{CH}_{4}, \mathrm{~N}_{2}, \mathrm{C}_{2} \mathrm{H}_{6}, \mathrm{C}_{3} \mathrm{H}_{8}$, and $\mathrm{C}_{6} \mathrm{H}_{6}$ of the melt and fluid inclusions trapped in quartz and beryl within pegmatite indicate the magmatic origin; (3) the ${ }^{40} \mathrm{Ar}^{39} \mathrm{Ar}$ plateau age of pegmatite $(18.93 \pm 0.27 \mathrm{Ma})$ is similar to stage 5 quartz-pyrite-stibnite $(17.9 \pm 0.5 \mathrm{Ma})$.

The pegmatite and two-mica granite in the domes have the typical characteristics of S-type granite: (1) containing abundant Al-rich minerals, A/CNK: 1.07 1.24; $(2) \mathrm{w}\left(\mathrm{SiO}_{2}\right)$ : $73.26 \% \sim 74.33 \%, \mathrm{w}\left(\mathrm{K}_{2} \mathrm{O}\right) / \mathrm{w}\left(\mathrm{Na}_{2} \mathrm{O}\right): 1.1 \sim 1.2, \mathrm{w}(\mathrm{FeO}) / \mathrm{w}(\mathrm{Fe}+$ $\mathrm{Mn}): 0.64 \sim 0.76$; (3) the content of corundum molecules $>1 \%$ in the CIPW standard minerals $[112,113]$. Meanwhile, based on the facts that all the Fe-bearing minerals in Zhaxikang 
deposit are ferrous, and the magmatic-hydrothermal fluid is $\mathrm{CO}_{2}$-rich with minor $\mathrm{CH}_{4}, \mathrm{~N}_{2}, \mathrm{C}_{2} \mathrm{H}_{6}, \mathrm{C}_{3} \mathrm{H}_{8}$, and $\mathrm{C}_{6} \mathrm{H}_{6}$ [6], and the parent magma is most likely $\mathrm{S}$-type reduced magma. In consideration of the situation in the Renison Sn$\mathrm{W}$ deposit that we mentioned in Section 1, the ore-forming fluid is considered to exsolve from S-type reduced magma and the sulfides have heavier $\mathrm{Fe}$ isotopic compositions than ore-related igneous rocks [23]. The case in Zhaxikang deposit is contrary yet the pyrite from the first pulse of mineralization has the $\delta^{56} \mathrm{Fe}$ value of $-0.33 \%$ o $0.23 \%$ o that is much lighter than those of granitoids $(-0.08 \%$ to $0.59 \%)$ [22, 28]. Moreover, Heimann et al. [43] proposed that we would not expect Fe isotopic compositions of high F/Cl magmatic/hydrothermal systems to significantly deviate from the average of igneous rocks, hence as Xie et al. [6] considered that the Zhaxikang parent magma has high $\mathrm{F}$ contents, the magmatic-hydrothermal fluid in this genetic model would have the similar Fe isotopic compositions with granitoids, which is not in line with our fractionation models. Even if the parent magma in Zhaxikang orefield is oxidized-type and is similar to the magma related to I-type granitoids with $\delta^{56} \mathrm{Fe}$ values of $-0.04 \% \sim 0.59 \%$ in Tongling ore district (Figure 9(a)) [21, 22], it is still hard to produce so light $\delta^{56} \mathrm{Fe}_{i}$ value $(-0.5 \%$ o $-1 \%$ o). Similarity, $\mathrm{Zn}$ isotopic data do not support this genetic model, either. Chen et al. [54] studied the $\mathrm{Zn}$ isotopic fractionation during igneous process and suggested that the maximum $\mathrm{Zn}$ isotopic variation induced by high-temperature igneous processes is no larger than $\delta^{66} \mathrm{Zn} \sim 0.10 \%$. Besides this, Telus et al. [28] measured the $\delta^{66} \mathrm{Zn}$ values of pegmatite $(0.25 \% 0 \sim 0.59 \% 0)$ and some other granitoids $(-0.16 \% \circ \sim 0.21 \%$ ) and then found there is even no variation in $\delta^{66} \mathrm{Zn}$ values during fluid exsolution in some cases. As the granitoids in the regional domes are principally dominated by pegmatite and the magmatic fluids which have high temperature of $298 \sim 457^{\circ} \mathrm{C}$ [6], it is also hard to generate $\delta^{66} \mathrm{Zn}_{i}$ value between $-0.28 \%$ and $0 \%$ as yielded from the $\mathrm{Fe}-\mathrm{Zn}$ isotopic fractionation models. Consequently, the Fe$\mathrm{Zn}$ isotopic data are also not in favor of the second genetic model.

On the other hand, neither of these two genetic models can explain the different Fe- $\mathrm{Zn}$ isotopic and elemental variations in sample ZXK-2, which is considered to result from the overprint by the second pulse of mineralization. Overall, all of the Fe- $\mathrm{Zn}$ isotopic and elemental evidences are inconsistent with both of these magmatic-hydrothermal fluid genetic models. Nevertheless, the evidence for these two genetic models may prove that the second pulse of mineralization is related to magmatic-hydrothermal fluids.

\subsubsection{Constraints on SEDEX Modified by Hydrothermal Fluid} Genetic Model. Zheng et al. [7, 25] considered that the first pulse of mineralization $(\mathrm{Pb}-\mathrm{Zn})$ has the SEDEX genesis, and the second pulse of mineralization ( $\mathrm{Sb}-\mathrm{Ag}$ ) is related to hot spring that overprints the earlier mineralization. The previous evidences are mainly as follows: (1) the evidence from ore textures and obviously late $\mathrm{Sb}$ mineralization compared to $\mathrm{Pb}-\mathrm{Zn}$ mineralization in Section 2.3; (2) the stage 1 and 2 ores have high $\mathrm{Mn}, \mathrm{Fe}, \mathrm{Ba}$, and $\mathrm{B}$ contents, $\mathrm{Ga} \gg \mathrm{In}$
(Ga/In: 1.49 4.47), $\mathrm{Pb}+\mathrm{Zn} \gg \mathrm{Cu}$, and host rocks are exhalative rocks and Mn-Fe carbonates; (3) the $\delta^{34} \mathrm{~S}$ values of sphalerite and galena $\left(7.7 \% \%_{0} \sim 12 \%\right.$ ) are different from those of stibnite $(4.5 \% 0200 \mathrm{~B} \sim 7.1 \% \mathrm{o}) ;(4)$ the data from valentinite $\left(\delta^{30} \mathrm{Si}\right.$ values: $-0.9 \%$ - $0.4 \%$ ) and fluid inclusions trapped in quartz $\left(\delta \mathrm{D}_{\mathrm{V}-\mathrm{SMOW}}\right.$ : $-162 \%$ o $-142 \%$, $\delta^{18} \mathrm{O}_{\mathrm{H}_{2} \mathrm{O}}$ : $-12.9 \%$ - $1.9 \%$, homogenization and freezing temperatures: $164 \sim 313^{\circ} \mathrm{C}$ and $-3.2 \sim-0.7^{\circ} \mathrm{C}$, salinity: $0.7 \% \sim 5.3 \%$, and density: $0.74 \sim 0.93 \mathrm{~g} / \mathrm{cm}^{3}$ ) both demonstrate the Sb mineralization is related to the south Tibetan hot spring; (5) the $\mathrm{Rb}-\mathrm{Sr}$ isotopic isochrone age of stage 2 sphalerite is $147.2 \pm$ 3.2 Ma that is similar to the Jurassic sedimentary wall rocks, whereas a later stage quartz-pyrite-stibnite vein has the ${ }^{40} \mathrm{Ar}$ ${ }^{39}$ Ar plateau age of $17.9 \pm 0.5 \mathrm{Ma}$.

Wen et al. [17] investigated several $\mathrm{Pb}-\mathrm{Zn}$ deposits with different geneses in China, and the results show that the $\mathrm{Zn} / \mathrm{Cd}$ ratios of sphalerite vary with different geneses: (1) high-temperature systems including the porphyry, magmatic hydrothermal, skarn, and volcanic hosted massive sulfide (VMS)-type deposits: 155 223; (2) low-temperature systems that include the Mississippi Valley-type (MVT) deposits: 17 201; (3) SEDEX-type deposits of exhalative systems: 316 368; (4) seafloor hydrothermal sulfides of exhalative systems: 211 510. According to the EPMA data, the $\mathrm{Zn} / \mathrm{Cd}$ ratios of sphalerite range from 296 to 399 in Zhaxikang deposit, which overlap the range of exhalative systems and much higher than those of high-temperature and low-temperature systems.

The Fe- $\mathrm{Zn}$ isotopic data also conform to the SEDEX modified by hydrothermal fluid genetic model. Firstly, as discussed in Sections 5.3.1 and 5.3.2, neither the hot spring nor the magmatic-hydrothermal fluids can have the $\delta^{56} \mathrm{Fe}_{i}$ $(-0.5 \%$ o $-1 \%$ o $)$ and $\delta^{66} \mathrm{Zn}_{i}(-0.28 \%$ o $0 \%$ ) values to satisfy the $\mathrm{Fe}-\mathrm{Zn}$ isotopic fractionation models. However, the Fe$\mathrm{Zn}$ isotopic compositions of seafloor hydrothermal fluid system covers the range of $-1.79 \%$ o $0.04 \%$ for Fe isotope and $-0.28 \%$ \% $0.96 \%$ o for $\mathrm{Zn}$ isotope according to previous studies (Figure 9) [38, 46-49, 62], which can generate the ore-forming system with $\delta^{56} \mathrm{Fe}_{i}$ and $\delta^{66} \mathrm{Zn}_{i}$ values to meet the fractionation models. Secondly, although there are large overlaps in $\mathrm{Zn}$ isotopic compositions among deposits with different geneses, the $\mathrm{Zn}$ isotopic compositions of Zhaxikang deposit is most similar to the Alexandrinka VHMS-type and Red Dog SEDEX-type deposits with marine origin, as well as obviously distinguishing from the narrow range of magmatic-hydrothermal deposits (Figure 9(b)). Thirdly, the lightest $\delta^{56} \mathrm{Fe}$ value in Zhaxikang deposit is $-1.95 \%$, and only the minerals with marine origin (mid-oceanic ridges pyrite) or SEDEX genesis (sphalerite and pyrrhotite in Dongshengmiao SEDEX-type deposit) can have so light $\delta^{56} \mathrm{Fe}$ values (Figure $9(\mathrm{a})$ ). Fourthly, under the conditions of high $P_{\mathrm{CO}_{2}}$ and low $\mathrm{PH}(<8)$, the $\mathrm{Zn}$ precipitated as sulfides is isotopically nearly unfractionated with respect to the parent hydrothermal fluid, whereas, under the conditions of high $P_{\mathrm{CO}_{2}}$ and high-PH (>9), negative $\delta^{66} \mathrm{Zn}$ values down to $0.6 \%$ can be expected in sulfides precipitated from hydrothermal fluid [107]. In Zhaxikang deposit, $P_{\mathrm{CO}_{2}}$ would be high as there are plenty of $\mathrm{Mn}$-Fe carbonates; meanwhile, owing to the facts that the modern seawater has the $\mathrm{PH}$ around 8 
and there is more $\mathrm{CO}_{2}$ in Jurassic atmosphere than present, the Jurassic seawater would have a lower PH than modern seawater. This can well explain that the $\delta^{66} \mathrm{Zn}$ values of sphalerite $(-0.38 \% 0 \sim 0.07 \%$ ) slightly fractionate with the ore-forming system $\left(\delta^{66} \mathrm{Zn}_{i}\right.$ value: $-0.28 \%$ \% $0 \%$ o). Besides these, the overprinting of earlier ores by second pulse of mineralization is not only proved by the different Fe- $\mathrm{Zn}$ isotopic and elemental variations in sample ZXK-2 from the other 3 samples in this research (Figure 5) but also evidenced by the temporally increasing $\delta^{56} \mathrm{Fe}$ and decreasing $\delta^{66} \mathrm{Zn}$ values recorded in this deposit that coincided with an increase in alteration [26]. Nevertheless, further research is required to confirm whether this hydrothermal fluid is hot spring or magmatic-hydrothermal fluid.

To sum up, among the various genetic models, the Fe- $\mathrm{Zn}$ isotopic and EPMA evidence indicate the SEDEX modified by hydrothermal fluid genetic model is the most plausible. Our research also demonstrates that the $\mathrm{Fe}-\mathrm{Zn}$ isotopes have the potential to trace the metal source and provide insights into ore-forming processes.

\section{Conclusions}

The EPMA and Fe- $\mathrm{Zn}$ isotopic data allow us to make the following conclusions:

(1) The ore-forming elements are transported by the ore-forming system that is the mixture of vapour and liquid phases; the vapour-liquid partitioning and mineral precipitation are the main cause of $\mathrm{Fe}-\mathrm{Zn}$ isotopic and elemental variations.

(2) The Fe- $\mathrm{Zn}$ isotopic fractionation models demonstrate that the $\delta^{56} \mathrm{Fe}_{i}$ and $\delta^{66} \mathrm{Zn}_{i}$ values of the oreforming system are in the range of $-0.5 \%$ $~-1 \%$ and $-0.28 \%$ o $0 \%$, respectively.

(3) Based on the evidence from the EPMA data, Fe$\mathrm{Zn}$ isotopic characteristics, and fractionation models, the SEDEX modified by hydrothermal fluid genetic model is most plausible for the Zhaxikang deposit.

(4) There are two pulses of mineralization in the Zhaxikang deposit; the overprint by the second pulse of mineralization has also partly modified the Fe- $\mathrm{Zn}$ isotopic and elemental compositions of some earlier samples.

\section{Conflicts of Interest}

The authors declare that they do not have any commercial or associative interest that represents conflicts of interest in connection with the submitted work.

\section{Acknowledgments}

This work was carried out while Da Wang was a visiting student at the Juniata College. The authors would like to thank Matthew Gonzalez (Pennsylvania State University) and Linda Godfrey (Rutgers University) for aid in measuring and access to the Neptune instruments. They acknowledge support from the Program for Changjiang Scholars and Innovative University Research Teams (IRT14R54, IRT1083), the Commonwealth Project from the Ministry of Land and Resources (201511015), and the Fundamental Research Funds for the Central Universities (2652015044 and 2652015354).

\section{References}

[1] W. Liang, Z. Q. Hou, Z. S. Yang et al., "Remobilization and overprinting in the Zhaxikang $\mathrm{Pb}-\mathrm{Zn}-\mathrm{Ag}$-Sb polymetal ore deposit, Southern Tibet: Implications for its metallogenesis," Acta Petrologica Sinica, vol. 29, no. 11, pp. 3828-3842, 2013 (Chinese).

[2] X. Sun, Y. Zheng, F. Pirajno et al., "Geology, S-Pb isotopes, and 40Ar/39Ar geochronology of the Zhaxikang $\mathrm{Sb}-\mathrm{Pb}-\mathrm{Zn}-\mathrm{Ag}$ deposit in Southern Tibet: implications for multiple mineralization events at Zhaxikang," Mineralium Deposita, pp. 1-24, 2017.

[3] X. J. Meng, Z. S. Yang, X. X. Qi, Z. Q. Hou, and Z. Q. Li, "Siliconoxygen-hydrogen isotopic compositions of Zhaxikang antimony polymetallic deposit in Southern Tibet and its responses to the ore-controlling structure," Acta Petrologica Sinica, vol. 24, no. 7, pp. 1649-1655, 2008 (Chinese).

[4] J. F. Zhang, Y. Y.Zheng, G. Y. Zhang et al., "Genesis of Zhaxikang $\mathrm{Pb}-\mathrm{Zn}$-Sb-Ag deposit in northern Himalaya: constraints from multi-isotope geochemistry," Earth Science Journal of China University of Geosciences, vol. 35, pp. 1000-1010, 2010 (Chinese).

[5] J. L. Duan, J. X. Tang, and B. Lin B, "Zinc and lead isotope signatures of the Zhaxikang $\mathrm{Pb} \mathrm{Zn}$ deposit, South Tibet: Implications for the source of the ore-forming metals," Ore Geology Review, vol. 78, pp. 58-68, 2016.

[6] Y. Xie, L. Li, B. Wang et al., "Genesis of the Zhaxikang epithermal $\mathrm{Pb}-\mathrm{Zn}$-Sb deposit in southern Tibet, China: Evidence for a magmatic link," Ore Geology Reviews, vol. 80, pp. 891-909, 2017.

[7] Y. Y. Zheng, M. Y. Liu, X. Sun et al., "Type, discovery process and significance of Zhaxikang antimony polymetallic ore deposit, Tibet," Earth Science Journal of China University of Geosciences, vol. 37, no. 5, pp. 1004-1014, 2012 (Chinese).

[8] H. P. Taylor Jr., "The application of oxygen and hydrogen isotope studies to problems of hydrothermal alteration and ore deposition,” Economic Geology, vol. 69, no. 6, pp. 843-883, 1974.

[9] M. J. Le Bas, B. Spiro, and Y. Xueming, “Oxygen, carbon and strontium isotope study of the carbonatitic dolomite host of the Bayan Obo Fe-Nb-REE deposit, Inner Mongolia, N China," Mineralogical Magazine, vol. 61, no. 4, pp. 531-541, 1997.

[10] Y. Wang and X.-K. Zhu, "Fe isotope systematics and its implications in ore deposit geology," Acta Petrologica Sinica, vol. 28, no. 11, pp. 3638-3654, 2012.

[11] J. W. Hedenquist and J. B. Lowenstern, "The role of magmas in the formation of hydrothermal ore deposits," Nature, vol. 370, no. 6490, pp. 519-527, 1994.

[12] Y. Wang and X. K. Zhu, "Application of Zn Isotopes to study of Mineral Deposits: A review," Mineral Deposits, vol. 29, no. 5, pp. 843-852, 2010 (Chinese).

[13] Y. Wang and X. K. Zhu, "Applications of Cu isotopes on studies of mineral deposits: A status report," Journal of Jilin University (Earth Science Edition), vol. 40, no. 4, pp. 739-751, 2010.

[14] C. N. Maréchal, P. Télouk, and F. Albarède, "Precise analysis of copper and zinc isotopic compositions by plasma-source mass spectrometry," Chemical Geology, vol. 156, no. 1-4, pp. 251-273, 1999. 
[15] N. S. Belshaw, X.-K. Zhu, Y. Guo, and R. K. O’Nions, "High precision measurement of iron isotopes by plasma source mass spectrometry," International Journal of Mass Spectrometry, vol. 197, no. 1-3, pp. 191-195, 2000.

[16] R. Mathur, S. Titley, F. Barra et al., "Exploration potential of $\mathrm{Cu}$ isotope fractionation in porphyry copper deposits," Journal of Geochemical Exploration, vol. 102, no. 1, pp. 1-6, 2009.

[17] H. J. Wen, C. W. Zhu, Y. X. Zhang, C. Cloquet, H. F. Fan, and $\mathrm{S}$. H. Fu, " $\mathrm{Zn} / \mathrm{Cd}$ ratios and cadmium isotope evidence for the classification of lead-zinc deposits," Scientific Reports, vol. 6, p. 25273, 2016.

[18] T. F. D. Mason, D. J. Weiss, J. B. Chapman et al., "Zn and $\mathrm{Cu}$ isotopic variability in the Alexandrinka volcanic-hosted massive sulphide (VHMS) ore deposit, Urals, Russia," Chemical Geology, vol. 221, no. 3-4, pp. 170-187, 2005.

[19] J. J. Wilkinson, D. J. Weiss, T. F. D. Mason, and B. J. Coles, "Zinc isotope variation in hydrothermal systems: Preliminary evidence from the Irish midlands ore field," Economic Geology, vol. 100, no. 3, pp. 583-590, 2005.

[20] K. D. Kelley, J. J. Wilkinson, J. B. Chapman, H. L. Crowther, and D. J. Weiss, "Zinc isotopes in sphalerite from base metal deposits in the Red Dog district, northern Alaska," Economic Geology, vol. 104, no. 6, pp. 767-773, 2009.

[21] Y. Wang, X.-K. Zhu, J.-W. Mao, Z.-H. Li, and Y.-B. Cheng, "Iron isotope fractionation during skarn-type metallogeny: A case study of Xinqiao Cu-S-Fe-Au deposit in the Middle-Lower Yangtze valley," Ore Geology Reviews, vol. 43, no. 1, pp. 194-202, 2011.

[22] Y. Wang, X.-K. Zhu, and Y. Cheng, "Fe isotope behaviours during sulfide-dominated skarn-type mineralisation," Journal of Asian Earth Sciences, vol. 103, pp. 374-392, 2015.

[23] C. M. Wawryk and J. D. Foden, "Fe-isotope fractionation in magmatic-hydrothermal mineral deposits: A case study from the Renison Sn-W deposit, Tasmania," Geochimica et Cosmochimica Acta, vol. 150, pp. 285-298, 2015.

[24] A. Yin, "Cenozoic tectonic evolution of the Himalayan orogen as constrained by along-strike variation of structural geometry, exhumation history, and foreland sedimentation," Earth-Science Reviews, vol. 76, no. 1-2, pp. 1-131, 2006.

[25] Y. Zheng, X. Sun, L. Tian et al., "Mineralization, deposit type and metallogenic age of the gold antimony polymetallic belt in the eastern part of North Himalayan," Geotectonica et Metallogenia, vol. 38, no. 1, pp. 108-118, 2014.

[26] D. Wang, X. Sun, Y. Zheng et al., "Two pulses of mineralization and genesis of the Zhaxikang $\mathrm{Sb}-\mathrm{Pb}-\mathrm{Zn}-\mathrm{Ag}$ deposit in southern Tibet: Constraints from Fe-Zn isotopes," Ore Geology Reviews, vol. 84, pp. 347-363, 2017.

[27] A. Fernandez and D. M. Borrok, "Fractionation of Cu, Fe, and $\mathrm{Zn}$ isotopes during the oxidative weathering of sulfide-rich rocks," Chemical Geology, vol. 264, no. 1-4, pp. 1-12, 2009.

[28] M. Telus, N. Dauphas, F. Moynier et al., "Iron, zinc, magnesium and uranium isotopic fractionation during continental crust differentiation: The tale from migmatites, granitoids, and pegmatites," Geochimica et Cosmochimica Acta, vol. 97, pp. 247-265, 2012.

[29] T. M. Harrison, P. Copeland, W. S. F. Kidd, and A. Yin, "Raising tibet," Science, vol. 255, no. 5052, pp. 1663-1670, 1992.

[30] M. A. Murphy, A. Yin, P. Kapp et al., "Structural evolution of the Gurla Mandhata detachment system, southwest Tibet," Geological Society of America Bulletin, vol. 114, no. 4, pp. 428$447,2002$.
[31] G. T. Pan, X. X. Mo, Z. Q. Hou et al., "Spatial-temporal framework of the Gangdese Orogenic Belt and its evolution," Acta Petrologica Sinica, vol. 22, pp. 521-533, 2006 (Chinese).

[32] J. E. Spratt, A. G. Jones, K. D. Nelson et al., "Crustal structure of the India-Asia collision zone, southern Tibet, from INDEPTH MT investigations," Physics of the Earth and Planetary Interiors, vol. 150, no. 1-3, pp. 227-237, 2005.

[33] G. M. Yu and C. S. Wang, Sedimentary Geology of Tethys, Tibet, Geology Publishing House, Beijing, China, 1999.

[34] B. L. Beard, C. M. Johnson, J. L. Skulan, K. H. Nealson, L. Cox, and H. Sun, "Application of Fe isotopes to tracing the geochemical and biological cycling of Fe," Chemical Geology, vol. 195, no. 1-4, pp. 87-117, 2003.

[35] O. J. Rouxel, A. Bekker, and K. J. Edwards, "Iron isotope constraints on the Archean and Paleoproterozoic ocean redox state," Science, vol. 307, no. 5712, pp. 1088-1091, 2005.

[36] B. L. Beard and C. M. Johnson, "High precision iron isotope measurements of terrestrial and lunar materials," Geochimica et Cosmochimica Acta, vol. 63, no. 11-12, pp. 1653-1660, 1999.

[37] X. K. Zhu, Y. Guo, R. J. P. Williams, R. K. O'Nions, A. Matthews, and N. S. Belshaw, "Mass fractionation processes of transition metal isotopes," Earth and Planetary Science Letters, vol. 200, no. 1, pp. 47-62, 2002.

[38] B. L. Beard, C. M. Johnson, K. L. Von Damm, and R. L. Poulson, "Iron isotope constraints on Fe cycling and mass balance in oxygenated Earth oceans," Geology, vol. 31, no. 7, pp. 629-632, 2003.

[39] F. Poitrasson, A. N. Halliday, D.-C. Lee, S. Levasseur, and N. Teutsch, "Iron isotope differences between Earth, Moon, Mars and Vesta as possible records of contrasted accretion mechanisms," Earth and Planetary Science Letters, vol. 223, no. 3-4, pp. 253-266, 2004.

[40] F. Poitrasson and R. Freydier, "Heavy iron isotope composition of granites determined by high resolution MC-ICP-MS," Chemical Geology, vol. 222, no. 1-2, pp. 132-147, 2005.

[41] N. Dauphas, P. E. Janney, R. A. Mendybaev et al., "Chromatographic separation and multicollection-ICPMS analysis of iron. Investigating mass-dependent and-independent isotope effects," Analytical Chemistry, vol. 76, no. 19, pp. 5855-5863, 2004.

[42] N. Dauphas, F.-Z. Teng, and N. T. Arndt, "Magnesium and iron isotopes in 2.7 Ga Alexo komatiites: Mantle signatures, no evidence for Soret diffusion, and identification of diffusive transport in zoned olivine," Geochimica et Cosmochimica Acta, vol. 74, no. 11, pp. 3274-3291, 2010.

[43] A. Heimann, B. L. Beard, and C. M. Johnson, "“The role of volatile exsolution and sub-solidus fluid/rock interactions in producing high ${ }^{56} \mathrm{Fe} /{ }^{54} \mathrm{Fe}$ ratios in siliceous igneous rocks," Geochimica et Cosmochimica Acta, vol. 72, no. 17, pp. 4379-4396, 2008.

[44] J. A. Schuessler, R. Schoenberg, and O. Sigmarsson, "Iron and lithium isotope systematics of the Hekla volcano, Iceland Evidence for $\mathrm{Fe}$ isotope fractionation during magma differentiation," Chemical Geology, vol. 258, no. 1-2, pp. 78-91, 2009.

[45] J. Foden, P. A. Sossi, and C. M. Wawryk, "Fe isotopes and the contrasting petrogenesis of A-, I-and S-type granite," Lithos, vol. 212, pp. 32-44, 2015.

[46] M. Sharam, M. Polizzotto, and A. D. Anbar, "Iron isotopes in hot springs along the Juan de Fuca Ridge," Earth and Planetary Science Letters, vol. 194, no. 1, pp. 39-51, 2011. 
[47] S. Severmann, C. M. Johnson, B. L. Beard et al., "The effect of plume processes on the Fe isotope composition of hydrothermally derived $\mathrm{Fe}$ in the deep ocean as inferred from the Rainbow vent site, Mid-Atlantic Ridge, 36॰14/N," Earth and Planetary Science Letters, vol. 225, no. 1-2, pp. 63-76, 2004.

[48] O. Rouxel, W. C. Shanks III, W. Bach, and K. J. Edwards, "Integrated Fe- and S-isotope study of seafloor hydrothermal vents at East Pacific Rise 9-10॰N," Chemical Geology, vol. 252, no. 3-4, pp. 214-227, 2008.

[49] S. A. Bennett, O. Rouxel, K. Schmidt, D. Garbe-Schoznberg, P. J. Statham, and C. R. German, "Iron isotope fractionation in a buoyant hydrothermal plume, 5०S Mid-Atlantic Ridge," Geochimica et Cosmochimica Acta, vol. 73, no. 19, pp. 5619-5634, 2009.

[50] O. Rouxel, Y. Fouquet, and J. N. Ludden, "Subsurface processes at the lucky strike hydrothermal field, Mid-Atlantic ridge: Evidence from sulfur, selenium, and iron isotopes," Geochimica et Cosmochimica Acta, vol. 68, no. 10, pp. 2295-2311, 2004.

[51] J. Sun, X. Zhu, Y. Chen, and N. Fang, "Iron isotopic constraints on the genesis of Bayan Obo ore deposit, Inner Mongolia, China," Precambrian Research, vol. 235, pp. 88-106, 2013.

[52] G. Markl, F. von Blanckenburg, and T. Wagner, "Iron isotope fractionation during hydrothermal ore deposition and alteration," Geochimica et Cosmochimica Acta, vol. 70, no. 12, pp. 3011-3030, 2006.

[53] Z. Gao, X. Zhu, J. Sun et al., "Spatial evolution of Zn-Fe-Pb isotopes of sphalerite within a single ore body: A case study from the Dongshengmiao ore deposit, Inner Mongolia, China," Mineralium Deposita, pp. 1-11, 2017.

[54] H. Chen, P. S. Savage, F. Z. Teng, R. T. Helz, and F. Moynier, "Zinc isotope fractionation during magmatic differentiation and the isotopic composition of the bulk Earth," Earth and Planetary Science Letters, vol. 369, pp. 34-42, 2013.

[55] C. N. Maréchal, N. Emmanuel, D. Chantal, and A. Francis, "Abundance of zinc isotopes as a marine biogeochemical tracer," Geochemistry, Geophysics, Geosystems, vol. 1, no. 5, 2000.

[56] D. J. Weiss, N. Rausch, T. F. D. Mason et al., "Atmospheric deposition and isotope biogeochemistry of zinc in ombrotrophic peat," Geochimica et Cosmochimica Acta, vol. 71, no. 14, pp. 3498-3517, 2007.

[57] Y. Bentahila, D. Ben Othman, and J.-M. Luck, "Strontium, lead and zinc isotopes in marine cores as tracers of sedimentary provenance: A case study around Taiwan orogen," Chemical Geology, vol. 248, no. 1-2, pp. 62-82, 2008.

[58] J.-P. Toutain, J. Sonke, M. Munoz et al., "Evidence for $\mathrm{Zn}$ isotopic fractionation at Merapi volcano," Chemical Geology, vol. 253, no. 1-2, pp. 74-82, 2008.

[59] J. Viers, P. Oliva, A. Nonell et al., "Evidence of $\mathrm{Zn}$ isotopic fractionation in a soil-plant system of a pristine tropical watershed (Nsimi, Cameroon)," Chemical Geology, vol. 239, no. 1-2, pp. 124-137, 2007.

[60] G. F. Herzog, F. Moynier, F. Albarède, and A. A. Berezhnoy, "Isotopic and elemental abundances of copper and zinc in lunar samples, Zagami, Pele's hairs, and a terrestrial basalt," Geochimica et Cosmochimica Acta, vol. 73, no. 19, pp. 5884$5904,2009$.

[61] S. Pichat, C. Douchet, and F. Albarède, "Zinc isotope variations in deep-sea carbonates from the eastern equatorial Pacific over the last 175 ka," Earth and Planetary Science Letters, vol. 210, no. 1-2, pp. 167-178, 2003.

[62] S. G. John, O. J. Rouxel, P. R. Craddock, A. M. Engwall, and E. A. Boyle, "Zinc stable isotopes in seafloor hydrothermal vent fluids and chimneys," Earth and Planetary Science Letters, vol. 269, no. 1-2, pp. 17-28, 2008.

[63] S. G. John and T. M. Conway, "A role for scavenging in the marine biogeochemical cycling of zinc and zinc isotopes," Earth and Planetary Science Letters, vol. 394, pp. 159-167, 2014.

[64] J.-X. Zhou, Z.-L. Huang, M.-F. Zhou, X.-K. Zhu, and P. Muchez, "Zinc, sulfur and lead isotopic variations in carbonate-hosted $\mathrm{Pb}-\mathrm{Zn}$ sulfide deposits, southwest China," Ore Geology Reviews, vol. 58, no. C, pp. 41-54, 2014.

[65] F. Albarède, "The stable isotope geochemistry of copper and zinc," Reviews in Mineralogy and Geochemistry, vol. 55, pp. 409427, 2004.

[66] G. Liu and G. Einsele, "Sedimentary history of the Tethyan basin in the Tibetan Himalayas," Geologische Rundschau, vol. 82, no. 1, pp. 32-61, 1994.

[67] P. Lefort, A. Yin, and T. M. Harrison, Evolution of the Himalaya. The tectonics of Asia, Cambridge University Press, New York, NY, USA, 1996.

[68] E. Garzanti, "Stratigraphy and sedimentary history of the Nepal Tethys Himalaya passive margin," Journal of Asian Earth Sciences, vol. 17, no. 5-6, pp. 805-827, 1999.

[69] R. Armijo, P. Tapponnier, J. L. Mercier, and T. L. Han, "Quaternary extension in southern Tibet: field observations and tectonic implications," Journal of Geophysical Research: Solid Earth, vol. 91, no. B14, pp. 13803-13872, 1986.

[70] P. England and G. Houseman, "Extension during continental convergence, with application to the Tibetan Plateau," Journal of Geophysical Research: Solid Earth, vol. 94, no. B12, pp. 17561$17579,1989$.

[71] A. Yin, "Mode of Cenozoic east-west extension in Tibet suggesting common origin of rifts in Asia during the Indo-Asian collision," Journal of Geophysical Research: Solid Earth, vol. 105, no. B9, pp. 21745-21759, 2000.

[72] Z. Li, Z. Hou, F. Nie, and X. Meng, "Characteristic and distribution of the partial melting layers in the upper crust: Evidence from active hydrothermal fluid in south Tibet," Acta Geologica Sinica, vol. 79, no. 1, pp. 69-77, 2005.

[73] M. Coleman and K. Hodges, "Evidence for Tibetan plateau uplift before $14 \mathrm{Myr}$ ago from a new minimum age for east-west extension," Nature, vol. 374, no. 6517, pp. 49-52, 1995.

[74] P. Kapp, M. Taylor, D. Stockli, and L. Ding, "Development of active low-angle normal fault systems during orogenic collapse: Insight from Tibet," Geology, vol. 36, no. 1, pp. 7-10, 2008.

[75] A. Yin, P. A. Kapp, M. A. Murphy et al., "Significant late Neogene east-west extension in northern Tibet," Geology, vol. 27, no. 9, pp. 787-790, 1999.

[76] H. Williams, S. Turner, S. Kelley, and N. Harris, "Age and composition of dikes in Southern Tibet: New constraints on the timing of east-west extension and its relationship to postcollisional volcanism," Geology, vol. 29, no. 4, pp. 339-342, 2001.

[77] S. H. Jiang, F. J. Nie, P. Hu, Y. Liu, and X. R. Lai, "Geochemical characteristics of the mafic dyke swarms in South Tibet," Acta Geological Sinica (English Edition), vol. 81, no. 1, pp. 60-71, 2007.

[78] J. S. Tong, J. Liu, H. M. Zhong, J. Xia, R. K. Lu, and Y. H. Li, "Zircon U-Pb dating and geochemistry of mafic dike swarms in the Lhozag area, southern Tibet, China, and their tectonic implications," Geological Bulletin of China, vol. 26, no. 12, pp. 1654-1664, 2007.

[79] Q. Bian and L. Ding, "Discovery of the Zhegucuo Au (As)bearing fine granular quartz diorite in the eastern Tethyan 
Himalayan Belt and its significance," Acta Petrologica Sinica, vol. 22, no. 4, pp. 977-988, 2006.

[80] G. T. Pan, L. Q. Wang, and D. C. Zhu, "Thoughts on some important scientific problems in regional geological survey of the Qinghai-Tibet plateau," Regional Geology of China, vol. 23, pp. 12-19, 2004.

[81] H. Zhong, J. Xia, J. Tong, R. Lu, Y. Li, and S. Xu, "New results and major progress in regional geological survey of the Lhozag County Sheet," Regional Geology of China, vol. 23, pp. 451-457, 2004.

[82] D.-C. Zhu, S.-L. Chung, X.-X. Mo et al., “The $132 \mathrm{Ma}$ Comei-Bunbury large igneous province: Remnants identified in present-day southeastern Tibet and southwestern Australia," Geology, vol. 37, no. 7, pp. 583-586, 2009.

[83] B. B. Qiu, D. C. Zhu, Z. D. Zhao, and L. Q. Wang, "The westward extension of Comei fragmented large igneous province in southern Tibet and its implications." Acta Petrologica Sinica, vol. 26, no. 7, pp. 2207-2216, 2010.

[84] F. J. Nie, P. Hu, S. H. Jiang, Z. Q. Li, and Y. Liu, "Type and temporal-spatial distribution of gold and antimony deposits (prospects) in Southern Tibet, China," Acta Geological SinicaEnglish Edition, vol. 79, no. 3, pp. 374-384, 2005.

[85] L. Zeng, L.-E. Gao, C. Dong, and S. Tang, "High-pressure melting of metapelite and the formation of Ca-rich granitic melts in the Namche Barwa Massif, southern Tibet," Gondwana Research, vol. 21, no. 1, pp. 138-151, 2012.

[86] M. P. Searle, R. R. Parrish, K. V. Hodges, A. Hurford, M. W. Ayres, and M. J. Whitehouse, "Shisha Pangma leucogranite, south Tibetan Himalaya: Field relations, geochemistry, age, origin, and emplacement," The Journal of Geology, vol. 105, no. 3, pp. 295-317, 1997.

[87] T. M. Harrison, P. Copeland, W. S. F. Kidd, and O. M. Lovera, "Activation of the Nyainqentanghla Shear Zone: Implications for uplift of the southern Tibetan Plateau," Tectonics, vol. 14, no. 3, pp. 658-676, 1995.

[88] Z. Hou, S. Tian, Z. Yuan et al., "The Himalayan collision zone carbonatites in western Sichuan, SW China: Petrogenesis, mantle source and tectonic implication," Earth and Planetary Science Letters, vol. 244, no. 1-2, pp. 234-250, 2006.

[89] Y. Y. Zheng, X. Sun, S. B. Gao et al., Target optimization and demonstrate research of Au-Sb Polymetallic Metallogenic Belt in Southern Tibet, Project Report. China University of Geoscience, Wuhan, China, 2016.

[90] B. Lin, J. X. Tang, W. B. Zheng et al., "Petrochemical features, zircon $\mathrm{U}-\mathrm{Pb}$ dating and $\mathrm{Hf}$ isotopic composition of the rhyolite in Zhaxikang deposit, Southern Xizang (Tibet)," Geological Review, vol. 60, no. 1, pp. 178-189, 2014.

[91] V. N. Korolyuk, Y. G. Lavrent'ev, L. V. Usova, and E. N. Nigmatulina, "Some features of X-ray registration using a JXA-8100 electron-probe microanalyzer," Journal of Analytical Chemistry, vol. 65, no. 3, pp. 249-254, 2010.

[92] W. Tian, B. Chen, T. R. Ireland, D. H. Green, K. Suzuki, and Z. $\mathrm{Chu}$, "Petrology and geochemistry of dunites, chromitites and mineral inclusions from the Gaositai Alaskan-type complex, North China Craton: Implications for mantle source characteristics," Lithos, vol. 127, no. 1-2, pp. 165-175, 2011.

[93] T. Yesavage, G. E. Stinchcomb, M. S. Fantle, P. B. Sak, A. Kasznel, and S. L. Brantley, "Investigation of a diabase-derived regolith profile from Pennsylvania: Mineralogy, chemistry and Fe isotope fractionation," Geoderma, vol. 273, pp. 83-97, 2016.

[94] C. Archer and D. Vance, "Mass discrimination correction in multiple-collector plasma source mass spectrometry: an example using $\mathrm{Cu}$ and $\mathrm{Zn}$ isotopes," Journal of Analytical Atomic Spectrometry, vol. 19, no. 5, pp. 656-665, 2004.

[95] J. B. Chapman, T. F. D. Mason, D. J. Weiss, B. J. Coles, and J. J. Wilkinson, "An adapted column chemistry procedure for separation of $\mathrm{Fe}, \mathrm{Cu}$ and $\mathrm{Zn}$ from geological matrices, and natural $\mathrm{Zn}$ isotopic variations in geological standard reference materials BCR-027, BCR-030 and NOD-P-1," Abstracts with Programs-Geological Society of America, vol. 36, p. 448, 2004.

[96] J. B. Chapman, T. F. D. Mason, D. J. Weiss, B. J. Coles, and J. J. Wilkinson, "Chemical separation and isotopic variations of $\mathrm{Cu}$ and $\mathrm{Zn}$ from five geological reference materials," Geostandards and Geoanalytical Research, vol. 30, no. 1, pp. 5-16, 2006.

[97] K. Peel, D. Weiss, J. Chapman, T. Arnold, and B. Coles, "A simple combined sample-standard bracketing and interelement correction procedure for accurate mass bias correction and precise $\mathrm{Zn}$ and $\mathrm{Cu}$ isotope ratio measurements," Journal of Analytical Atomic Spectrometry, vol. 23, no. 1, pp. 103-110, 2008.

[98] C. Archer, M. B. Andersen, C. Cloquet et al., "Inter-calibration of a proposed new primary reference standard AA-ETH Zn for zinc isotopic analysis," Journal of Analytical Atomic Spectrometry, vol. 32, no. 2, pp. 415-419, 2017.

[99] C. Archer, D. Vance, and I. Butler, "Abiotic Zn isotope fractionations associated with ZnS precipitation," 14th Annual VM Goldschmidt Conference. Geochimica et Cosmochimica Acta, vol. 68, no. 11, pp. A325-A325, 2004.

[100] D. Gagnevin, A. J. Boyce, C. D. Barrie, J. F. Menuge, and R. J. Blakeman, " $\mathrm{Zn}, \mathrm{Fe}$ and $\mathrm{S}$ isotope fractionation in a large hydrothermal system," Geochimica et Cosmochimica Acta, vol. 88, pp. 183-198, 2012.

[101] S. Graham, N. Pearson, S. Jackson, W. Griffin, and S. Y. O'Reilly, “Tracing $\mathrm{Cu}$ and Fe from source to porphyry: In situ determination of $\mathrm{Cu}$ and $\mathrm{Fe}$ isotope ratios in sulfides from the Grasberg Cu-Au deposit," Chemical Geology, vol. 207, no. 3-4, pp. 147-169, 2004.

[102] Z. Sharp, Principles of Stable Isotope Geochemistry, Pearson education, Upper Saddle River, NJ, USA, 2007.

[103] J. Yao, R. Mathur, W. Sun et al., "Fractionation of $\mathrm{Cu}$ and Mo isotopes caused by vapor-liquid partitioning, evidence from the Dahutang W-Cu-Mo ore field," Geochemistry, Geophysics, Geosystems, vol. 17, no. 5, pp. 1725-1739, 2016.

[104] M. Yu, Characteristics of ore geology and ore-forming fluid in the Zhaxikang Sb-Pb-Zn-Ag deposit, Southern Tibet, China [Msc. thesis], China University of Geoscience, Beijing, China, 2015.

[105] W. Dansgaard, "Stable isotopes in precipitation," Tellus, vol. 16, no. 4, pp. 436-468, 1964.

[106] V. B. Polyakov and D. M. Soultanov, "New data on equilibrium iron isotope fractionation among sulfides: Constraints on mechanisms of sulfide formation in hydrothermal and igneous systems," Geochimica et Cosmochimica Acta, vol. 75, no. 7, pp. 1957-1974, 2011.

[107] T. Fujii, F. Moynier, M.-L. Pons, and F. Albarède, "The origin of $\mathrm{Zn}$ isotope fractionation in sulfides," Geochimica et Cosmochimica Acta, vol. 75, no. 23, pp. 7632-7643, 2011.

[108] S. H. Little, D. Vance, C. Walker-Brown, and W. M. Landing, "The oceanic mass balance of copper and zinc isotopes, investigated by analysis of their inputs, and outputs to ferromanganese oxide sediments," Geochimica et Cosmochimica Acta, vol. 125, pp. 673-693, 2014.

[109] Y. Zhao, D. Vance, W. Abouchami, and H. J. W. de Baar, "Biogeochemical cycling of zinc and its isotopes in the Southern Ocean," Geochimica et Cosmochimica Acta, vol. 125, pp. 653672, 2014. 
[110] J.-B. Chen, J. Gaillardet, C. Dessert et al., "Zn isotope compositions of the thermal spring waters of la soufrière volcano, guadeloupe island," Geochimica et Cosmochimica Acta, vol. 127, pp. 67-82, 2014.

[111] H. C. Urey, "The thermodynamic properties of isotopic substances," Journal of the Chemical Society (Resumed), pp. 562-581, 1947.

[112] J. S. Tong, H. M. Zhong, J. Xia, R. K. Lu, and S. Y. Yang, "Geochemical features and tectonic setting of peraluminous granite in the Lhozag area, southern Tibet," Regional Geology of China, vol. 5, pp. 308-318, 2003 (Chinese).

[113] J. Y. Zhang, Q. A. Liao, D. W. Li, X. H. Zhang, and Y. M. Yuan, "Laguigangri leucogranites and its relation with laguigangri metamorphic core complex in Sajia, south Tibet," Earth Science (Journal of China University of Geosciences), vol. 28, no. 6, pp. 695-700, 2003 (Chinese). 

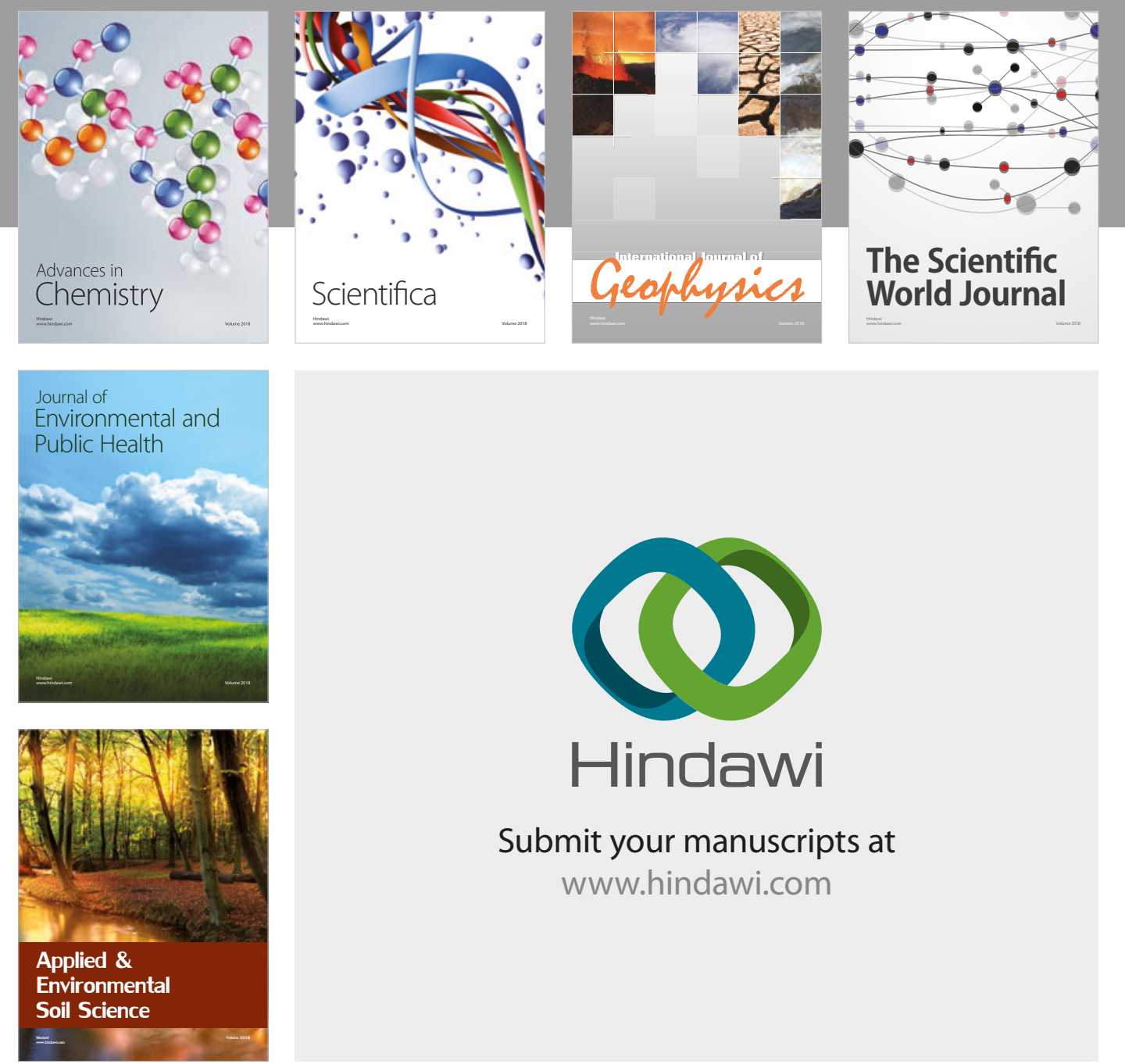

The Scientific

\section{World Journal}
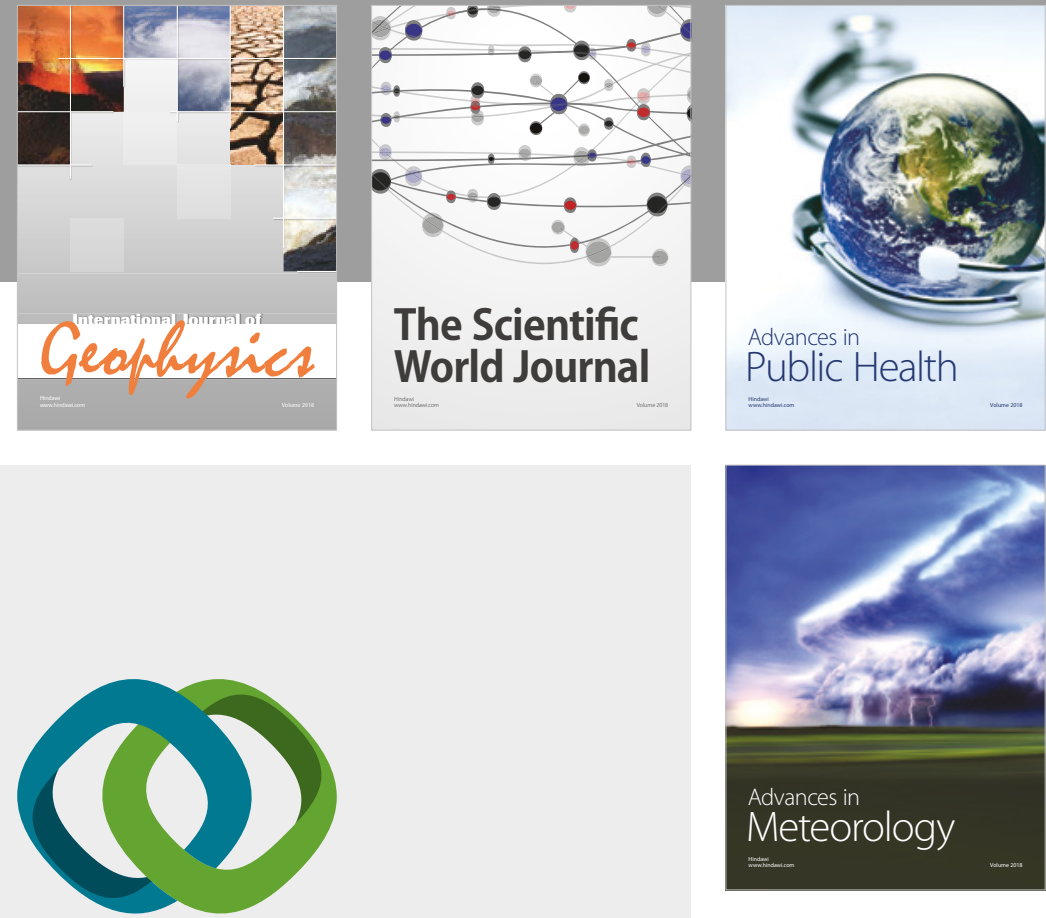

Advan

Public Health

\section{Hindawi}

Submit your manuscripts at

www.hindawi.com
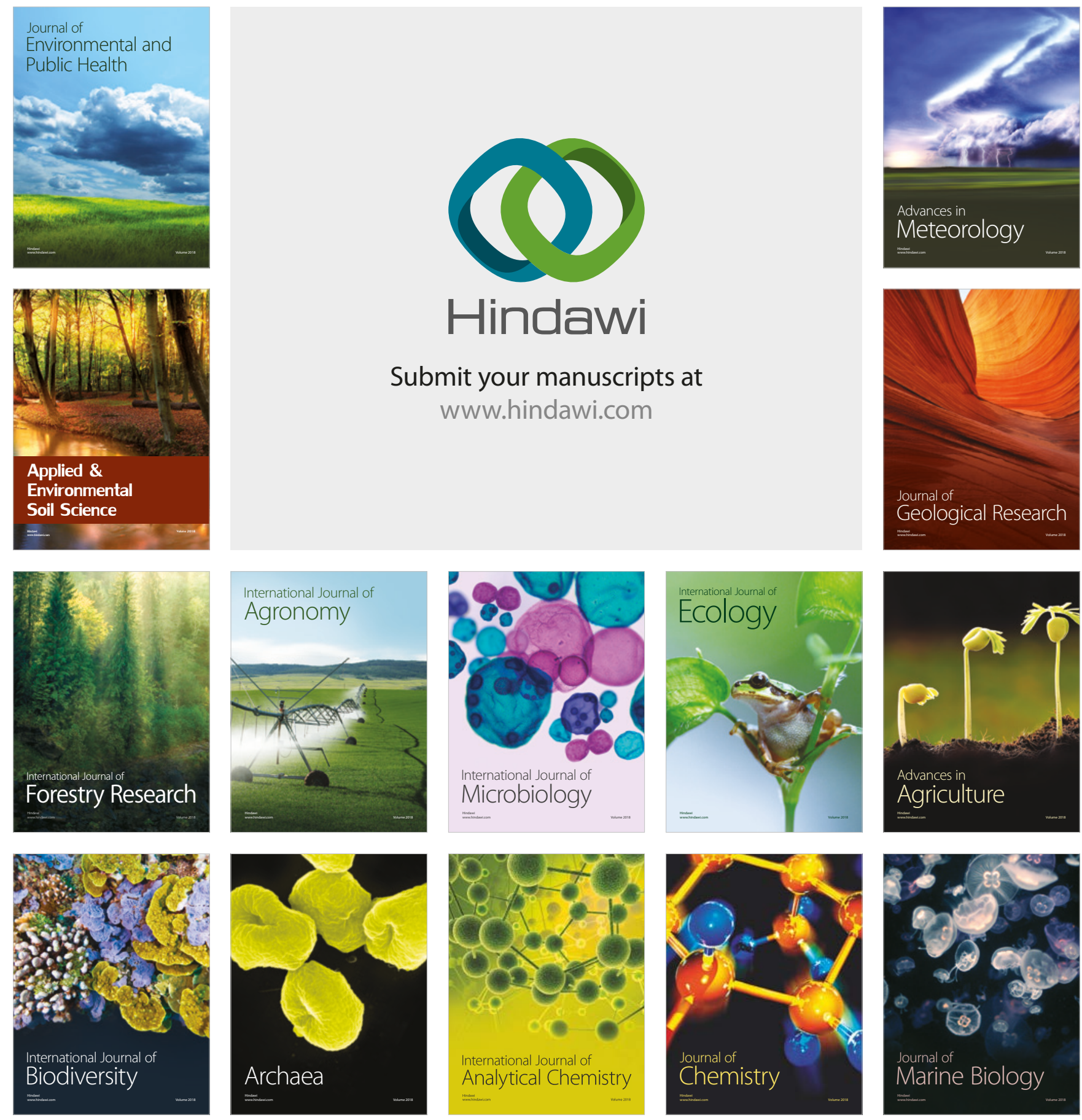